\title{
$\begin{array}{ll}\text { Research Square } & \text { Preprints are preliminary reports that have not undergone peer review. } \\ \text { They should not be considered conclusive, used to inform clinical practice, } \\ \text { or referenced by the media as validated information. }\end{array}$
}

\section{Dietary Coleus Amboinicus Herb Decreases Ruminal Methanogenesis and Biohydrogenation, and Improves Meat Quality and Fatty Acid Composition in Longissimus Thoracis of Lambs}

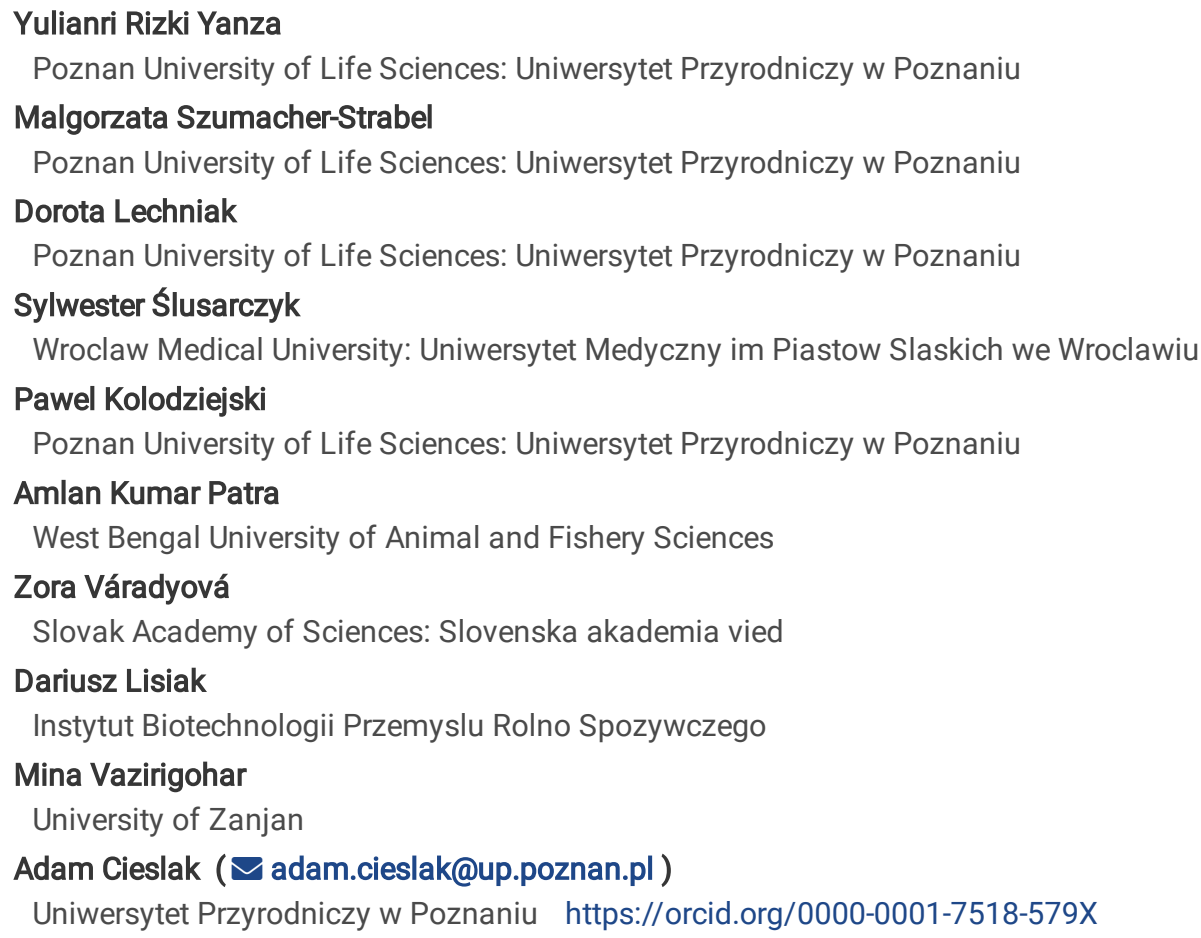

\section{Research}

Keywords: biologically active compounds, methane production, digestibility, ruminal microorganism populations, meat quality, fatty acids profiles

Posted Date: July 1st, 2021

DOI: https://doi.org/10.21203/rs.3.rs-663920/v1

License: (c) (1) This work is licensed under a Creative Commons Attribution 4.0 International License. Read Full License 


\section{Abstract}

Background: This study aimed to investigate the effect of biologically active compounds (BAC) of Coleus amboinicus Lour. (CAL) herb fed to growing lambs on ruminal methane production, ruminal biohydrogenation of unsaturated fatty acids and meat characteristics. An in vitro trial (Experiment 1) comprising of control and three experimental diets (CAL constituting 10\%, 15\%, and $20 \%$ of the total diet) was conducted to determine an effective dose for in vivo experiments. After the in vitro trial, two in vivo experiments were conducted on six growing, rumencannulated lambs (Experiment 2) and 16 growing lambs (Experiment 3), which were assigned into the control (CON) and one experimental diet ( $20 \%$ of CAL). Several parameters were examined in vitro ( $\mathrm{pH}$, ammonia and VFA concentrations, protozoa, methanogens and select bacteria populations) and in vivo (methane production, digestibility, ruminal microorganism populations, meat quality, fatty acids profiles in rumen fluid and meat, transcript expression of 5 genes in meat).

Results: The CAL lowered in vitro methane production by $51 \%$. In the in vivo experiments, lambs fed CAL decreased methane production by $20 \%$ compared with the CON animals (Experiment 3), which corresponded to the reduced total methanogens counts in all experiments up to $28 \%$, notably Methanobacteriales. In Experiment 3, CAL increased or tended to increase the numbers of Ruminococcus albus, Megasphaeraelsdenii, Butyrivibrioproteoclasticus, and Butyrivibriofibrisolvens. Dietary CAL suppressed the Holotricha population, but increased or tended to increase Entodiniomorpha population in Experiments 2 and 3. An increase in the polyunsaturated fatty acid (PUFA) proportion in the rumen of lambs was noted in response to the CAL diet, which was mainly attributable to the increase in C18:3 cis-9 cis-12 cis-15 (LNA) proportion. The CAL reduced the mRNA expressions of four investigated genes in meat (fatty acid synthase, stearoyl-CoA desaturase, lipoprotein lipase, and fatty acid desaturase 1).

Conclusions:Summarizing, polyphenols of CAL (20\% in diet) origin can mitigate ruminal methane production by inhibiting the methanogens communities. Supplementation of CAL also provides favorable conditions in the rumen by modulating ruminal bacteria involved in fermentation and biohydrogenation of fatty acids. CAL elevated the LNA concentration, which led to improved meat quality through increased deposition of n-3 PUFA.

\section{Highlight}

- Inclusion of Coleus amboinicus herb (CAH) into sheep diet decreased $\mathrm{CH}_{4}$ emission.

- CAH did not reduce nutrient digestibility, but inhibited the methanogen community.

- CAH increased ruminal propionate proportion and decreased acetate/propionate ratio.

- CAH elevated n-3 fatty acid concentration in ruminal fluid and meat.

- Supplementation of CAH improved some meat quality traits.

\section{Introduction}

Methane $\left(\mathrm{CH}_{4}\right)$ is a greenhouse gas mainly produced by anaerobic enteric fermentation in the rumen. It is estimated that farm animals produce $16 \%$ of the world's total $\mathrm{CH}_{4}$ emission, with two-thirds from ruminant origins [1]. This gas is considered as one of the main drivers of climate change and is expected to increase assuming a constant increase in demand of foods for a growing world population[2]. The enteric $\mathrm{CH}_{4}$ production from ruminants also represents a loss of the total gross dietary energy (2-12\%) that perhaps decreases the efficiency of animal production[3]. Enteric $\mathrm{CH}_{4}$ emission is thus one of the main targets of greenhouse gas mitigation efforts to reduce $\mathrm{CH}_{4}$ production in the animal sector.

Biologically active compounds (BACs) have been recognized as modulators of rumen microbial fermentation, including methanogenesis[4, 5]. As alternatives to antibiotics, BACs have the potential to decrease $\mathrm{CH}_{4}$ production in the rumen and can thus help to reduce the negative animal impact on the environment[6, 7]. The use of BACs may also modulate the ruminal biohydrogenation (BH) of unsaturated fatty acids (UFAs), causing changes in the fatty acid (FA) profile of the ruminal fluid and consequently of ruminant products. For instance, some BACs inhibit the microorganisms involved in ruminal $\mathrm{BH}$, and may consequently improve the quality of ruminant-derived products by increasing the content of UFAs $[8,9]$. Recent studies have strongly indicated that the reduction of ruminal $\mathrm{CH}_{4}$ production should be balanced with improvements in rumen performance, and enrichment of animal products with beneficial FAs for sustainable adoption of $\mathrm{CH}_{4}$ mitigation technologies in the livestock industry $[3,9]$. Researchers are still searching for the most effective sources and doses of BACs that could be recommended for longterm application.

One category of BACs are polyphenols, such as phenolic acids, flavonoids, condensed tannins and hydrolysable tannins[5]. Some plants rich in distinct polyphenol fractions exert antibacterial and antimethanogenic effects $[5,10,11]$. Coleus amboinicus Lour. (CAL) herb is rich in polyphenolic compounds (mostly phenolic acids and flavonoids), diterpenes, and alkaloids [10-13].C. amboinicus grows in tropical regions, 
including Asia, Africa and Australia, and is used in human medicine for long time[10, 14]. Our previous short-term in vitro study revealed the capacity of $\mathrm{CAL}$ to decrease $\mathrm{CH}_{4}$ production and to modulate ruminal FA composition, mainly n-3 polyunsaturated fatty acids (PUFAs) by altering the microbial activity linked to methanogenesis and FA biohydrogenation [13]. However, no trial involving polyphenol-rich CAL in a longterm in vivo experiment focusing on ruminal fermentation has been published to date. Therefore, this study investigated the long-term effects and mode of action of BACs of CAL on rumen methanogenesis and $\mathrm{BH}$ in growing lambs. We hypothesized that CAL could 1) affect rumen microbial population (mainly methanogens) and consequently mitigate ruminal $\mathrm{CH}_{4}$ production, and 2 ) modulate the $\mathrm{BH}$ of UFA, especially $\mathrm{n}-3$ PUFAs, in the rumen and animal tissues, presumably, without any negative effect on rumen parameters or animal performance.

\section{Materials And Methods Experimental design}

The CAL used in this study were purchased from a commercial source (Karya Herbal Nasional, company land-plot at Bogor, Indonesia $6^{\circ} 70^{\prime} 28^{\prime \prime S}$; $106^{\circ} 90^{\prime} 90^{\prime \prime} \mathrm{E}$ and $\left.6^{\circ} 43^{\prime} 30.1^{\prime \prime} \mathrm{S} ; 107^{\circ} 05^{\prime} 09.2^{\prime \prime} \mathrm{E}\right)$. The CAL were randomly collected after 2 to 3 -month growth period and dried in an oven at $50-60^{\circ} \mathrm{C}$ for $48 \mathrm{~h}$. The herb leaves were ground and prepared for analyses.

\section{In vitro experiment}

The Experiment 1 was carried out using a long-term in vitro system employing the rumen simulation technique (RUSITEC) developed by Czerkawski and Breckenridge[15]. The RUSITEC system had eight fermenters of one liter each. The fermenters were placed in a water bath maintained at $39^{\circ} \mathrm{C}$ throughout the five-day adaptation period and five-day sampling period. The in vitro experiment was designed with a completely randomized block design with four diets and two replicates in each run, and repeated three times. The four diets were as follows: diet 1: a control diet (CON, based on grass silage and concentrate at a 45:55 ratio; $11 \mathrm{~g}$ of DM); diet 2: $10 \%$ CAL (9.9 g DM of CON with 1.1 g DM of CAL); diet 3: 15\% CAL (9.35 g DM of CON with $1.65 \mathrm{~g} \mathrm{DM}$ of CAL diet), and diet 4: $20 \% \mathrm{CAL}$ (8.8 g DM of CON with $2.2 \mathrm{~g} \mathrm{DM}$ of CAL). The chemical composition of the grass silage, concentrate, and CAL are presented in Table 1. 
Table 1

Chemical composition and fatty acids profile of dietary components and CAL herb.

\begin{tabular}{|c|c|c|c|}
\hline Item & Grass Silage & Concentrate & CAL \\
\hline Dry matter content, $\mathrm{g} / \mathrm{kg}$ & 416 & 889 & 919 \\
\hline \multicolumn{4}{|c|}{ Chemicals composition, g/kg DM } \\
\hline Ash & 86.9 & 71.9 & 153 \\
\hline Organicmatter & 913 & 928 & 847 \\
\hline Crude protein & 187 & 203 & 214 \\
\hline Etherextract & 20.6 & 38 & 43.3 \\
\hline aNDF & 456 & 238 & 405 \\
\hline \multicolumn{4}{|l|}{ Fatty acids, g/100 g FA } \\
\hline $\mathrm{C} 14: 0$ & 0.90 & 0.20 & 0.45 \\
\hline $\mathrm{C} 16: 0$ & 19.9 & 16.3 & 18.7 \\
\hline C18:0 & 5.88 & 3.71 & 4.35 \\
\hline C18:1 cis- 9 & 8.8 & 23.7 & 2.5 \\
\hline C18:2 cis-9. cis- 12 & 14.4 & 42.7 & 10.8 \\
\hline C18:3 cis- 9 cis- 12 cis- 15 & 36.1 & 9.20 & 45.1 \\
\hline$\sum$ Other FA & 13.9 & 4.23 & 18.1 \\
\hline$\sum \mathrm{SFA}$ & 30.1 & 21.4 & 26 \\
\hline$\sum$ UFA & 69.9 & 78.6 & 74 \\
\hline$\sum$ MUFA & 14.3 & 26.2 & 14.8 \\
\hline$\sum$ PUFA & 55.5 & 52.5 & 59.2 \\
\hline$\sum n-6 F A$ & 17.7 & 43.0 & 12.3 \\
\hline$\sum n-3 F A$ & 37.8 & 9.42 & 46.9 \\
\hline
\end{tabular}

CAL, C. amboinicus herb; aNDF, NDF analyzed with a-amylase; FA, fatty acids; SFA, saturated fatty acids; UFA, unsaturated fatty acids; MUFA, monounsaturated fatty acids; PUFA, polyunsaturated fatty acids. 
Table 2

Contents of the phenolic acids, flavonoids, and diterpenes identified in CAL.

\begin{tabular}{|c|c|}
\hline Compounds & Content (mg/g DM) \\
\hline Siringingacid & 0.26 \\
\hline Vanilicacid & 0.060 \\
\hline Dihydroxybenzoicacid & 0.19 \\
\hline Hydroxybenzoicacid & 1.03 \\
\hline Caffeicacid & 3.20 \\
\hline Dihydroferulicacid-O-glucuronide & 0.25 \\
\hline Luteolin-O-(hexosyl) & 0.42 \\
\hline Luteolin-O-glucuronide & 4.34 \\
\hline Ferulicacid & 0.25 \\
\hline Rosmarinicacidderivative & 0.34 \\
\hline Apigenin-O-glucuronide & 2.89 \\
\hline Rosmarinicacid & 3.36 \\
\hline Luteolin-O-(maloylglycosyl) & 1.73 \\
\hline Apigenin derivative & 0.88 \\
\hline Carnosciacidglucoside & 0.080 \\
\hline Luteolin & 0.18 \\
\hline Luteolin-O-(rhamnosyl-hexosyl) & 0.15 \\
\hline Apigenin & 0.12 \\
\hline 3'.4'-Dimethoxyquercetin & 0.14 \\
\hline Salvianolicacid C & 0.27 \\
\hline Diterpenederivative & 0.37 \\
\hline Salvianolicacid C derivative & 0.12 \\
\hline 5.7-Dihydroxy-4'.6-dimethoxyflavone & 0.075 \\
\hline Dihydroxykaurenoicacid & 0.045 \\
\hline Trihydroxy-ent-kauranoicacid & 0.020 \\
\hline Rosmanol & 0.085 \\
\hline Dihydroxykaurenoicacid & 0.17 \\
\hline Longikaurin A & 0.28 \\
\hline Dihydroxyroyleanone & 4.78 \\
\hline Epirosmanol & 0.11 \\
\hline Dihydroxy-16-kauren-19-oic acid & 0.10 \\
\hline Diterpene & 0.22 \\
\hline Acetyldihydroxyroyleanone & 13.41 \\
\hline Total phenolicacids & 9.30 \\
\hline Total flavonoids & 10.94 \\
\hline Total polyphenoliccontent & 20.24 \\
\hline Total diterpenes & 19.59 \\
\hline
\end{tabular}

Page 5/29 
Rumen fluid and solid digesta for the in vitro experiment were collected before morning feeding from six rumen-cannulated lambs (20 $\pm 3 \mathrm{~kg}$ ) for microbial inocula. The lambs, donors of the rumen fluid, were fed the same diet as in the CON treatment. The animals were fed grass silage (300 g/of DM per day) and concentrate (360 g of DM per day). The ruminal contents were collected from the top, bottom, and middle parts of the rumen of each lamb separately, then strained through a four-layer cheesecloth into a prewarmed Schott Duran bottle (Schott, NY, USA), flushed with carbon dioxide $\left(\mathrm{CO}_{2}\right)$, and immediately transported to the laboratory in a $39^{\circ} \mathrm{C}$-preheated water bath. Before beginning the RUSITEC experiment, samples of ruminal fluid from each lamb were mixed in equal proportions and each fermenter was filled with 500 ml of strained rumen fluid and $400 \mathrm{ml}$ of prewarmed McDougall buffer[16]. Two nylon bags (70 $\times 140 \mathrm{~mm}, 100-\mu \mathrm{m}$ pore size) were put into the fermentersthe first nylon bag contained approximately $11 \mathrm{~g} \mathrm{DM}$ of rumen solid digesta, and the others contained $11 \mathrm{~g} \mathrm{DM}$ of the diets (CON, $10 \%$ CAL, $15 \%$ $\mathrm{CAL}$, or $20 \% \mathrm{CAL}$ ). After $24 \mathrm{~h}$ incubation, the nylon bag with rumen digesta was replaced with a new nylon bag containing diets. Finally, each bag with diet was incubated for $48 \mathrm{~h}$. After replacing each bag and closing the fermenter, the fermenter was flushed for 3 min (3 L/min) using $\mathrm{N}_{2}$ gas to reestablish anaerobic conditions. During the experimental runs, the buffer was supplied continuously into each fermenter by an electronic peristaltic pump (Miniplus 3, Gilson, Middleton, WI, USA) at an average buffer flow rate of $500 \mathrm{ml} /$ day consistently. The fermented fluid was continuously transferred through an overflow tube to the respective effluent vessels containing $10 \mathrm{ml}$ of $6 \mathrm{~N} \mathrm{HCl}$ (to stop the fermentation process). Samples of fermentation fluid were collected directly from each fermenter $3 \mathrm{~h}$ before replacing the bags with the diets. The $\mathrm{pH}$, ammonia concentration, VFA profile, feed degradability, protozoa count, and populations of methanogen, total bacteria, and select bacteria were analyzed. To determine FA profile, samples of the fermenting fluid were directly collected from the effluent vessels while the bags were being replaced. Fermentation gases were collected over 24 h using gas-tight bags (Tecobag 81, Tesseraux Container, Bürstadt, Germany).

\section{In vivo experiment}

The Experiment 2 employed six rumen-cannulated lambs allocated into two treatments, i.e., the control diet (CON) and the experimental diet (CAL-containing diet) in a crossover design. The highest level (20\%) of CAL was selected based on the in vitro results from RUSITEC experiment. The CON and CAL lambs were fed a combination of grass silage and concentrates to meet their nutrient requirements for growth (200 g/day). Lambs on CON diet received $400 \mathrm{~g} /$ day of concentrate and ad libitum grass silage, with daily intake of silage recorded.

Experimental lambs received CAL supplemented concentrate ( $400 \mathrm{~g} /$ day). During the first 14 days of the experiment, the lambs were adapted to gradually increased CAL levels: from $50 \mathrm{~g} /$ day to $200 \mathrm{~g} /$ day of the dry ground CAL. From the day 15 onwards, the lambs were feed $200 \mathrm{~g} / \mathrm{d}$ of dry CAL per day. The CAL lambs finally received $400 \mathrm{~g} /$ day of concentrate containing $200 \mathrm{~g} /$ day of CAL and ad libitum grass silage (the daily intake of silage was recorded). In Experiment 2, each period lasted 24 days, with a 21-day adaptation period and a 3-day sampling period. Rumen fluid from each lamb was collected every day for three days of the experimental period, before morning feeding ( $0 \mathrm{~h})$, and then at $3 \mathrm{~h}$ and $6 \mathrm{~h}$ after morning feeding [17]. The $\mathrm{pH}$, ammonia concentration, VFA profile, and numbers of protozoa, methanogens, and total bacteria were analyzed. Meanwhile, samples for quantification of total bacteria and methanogens using fluorescence in situ hybridization (FISH) were only collected at the $3 \mathrm{~h}$ timepoint.

In Experiment 3, sixteen growing lambs (20 $\pm 3 \mathrm{~kg}$ live weight) were used for the final production performance test. Lambs were randomly allocated into CON or CAL dietary treatments based on their live weight ( $n=8$ per group). Lambs were kept individually during the whole experiment, except during the period when respiratory chambers were used. In order to reduce stress associated with isolation, two animals were always kept together in each cage placed in the respiratory chamber.The experiment lasted 30 days: a 21-day adaptation stage and an 8day sampling period, with one day for the slaughtering process. During the adaptation period, the lambs were adapted to the CAL diet, as in Experiment 2. The CON lambs were fed a control diet of grass silage (ad libitum, but with recorded intake) and a concentrate mixture (400 $\mathrm{g} /$ day). The CAL lambs were also fed grass silage ad libitum with recorded intake, and a concentrate (400 g/day) containing CAL (200 g/day). All animals had free access to fresh water. The CON and CAL diets were fed in equal proportion at 8 am and 8 pm daily. Feed intake, feed residue, and amount of feces were recorded daily. Animal weights were recorded weekly. During the sampling period (from day 22 to day 28 of the experiment), each cage was transferred into a respiratory chamber by daily rotation in order to determine the direct $\mathrm{CH}_{4}$ emission for $24 \mathrm{~h}$ consecutively. Two respiratory chambers were used. Each cage was tested twicebut in order to obtain individual lamb's gasses production, obtained results were divided by two.

On the last day of experiment (day 29), the animals were slaughtered $3 \mathrm{~h}$ after morning feeding. After slaughtering, the rumen digesta were taken from the top, bottom, and middle of the rumen and squeezed through a four-layer cheese-cloth for analysis of $\mathrm{pH}$, ammonia concentration, and VFA profile in ruminal fluid, FA profile, and populations of protozoa, methanogens, total bacteria, and select bacteria in digesta. Samples of muscle from the right side of each carcass and drawn at the level of the thirteenth thoracic rib was immediately collected. Approximately $5 \mathrm{~g}$ of Longissimus thoracis (LT) muscle was shock-frozen in liquid nitrogen for gene expression analysis. The LT muscle (ca. 50 g) was cooled and transferred in a cool $\left(4^{\circ} \mathrm{C}\right)$ atmosphere to the laboratory for FA analysis. All collected samples were stored at $-80^{\circ} \mathrm{C}$ until analysis.

\section{Meat quality traits}


The LT (100 g) from the right-half carcass was used for meat quality analysis that was performed at the laboratory of the Institute of Agricultural and Food Biotechnology (Poland) following the procedures previously described in details by Grochowska et al. [18]. Briefly, the pH was measured in triplicates $24 \mathrm{~h}$ post-mortem on samples of LT muscle using a pHmeter with an integrated electrode (pH meter 1140, MettlerToledo, USA) following ISO 2917 (2001) instructions. For the instrumental evaluation of meat color, 10 mm thick steaks of LT muscle were cut towards the direction of muscle fibers and exposed to electric light for $15 \mathrm{~min}$. The values of L* (lightness), a* (redness), and b* (yellowness) were determined in triplicates using a Minolta Chroma Meter CR- 400 (Konica-Minolta, Japan). Compositional analysis of LT muscle (water, intramuscular fat (IMF) and total protein content) was performed using minced samples according to the methods described in ISO 1442 (2000) for water, ISO 1444 (2000) for fat (using a Soxtherm device, Gerhardt Analytical System, Germany), and PN-75/A-04018 (2000) for protein (using a Kjeltec System 1002 Distilling Unit, FOSS Analytical, Denmark). The water-holding capacity (WHC) of minced LT muscle samples was determined as described by Grau and Hamm [19], with later modifications introduced by Pohja and Ninivaara[20]. Visual evaluations of meat color and marbling of LT muscle samples were performed by a panel of four assessors using a 1-8 point Soicarni scale for meat color, with 1 being the lightest and 8 the darkest color, and a 1-4 point scale for marbling (developed by the Institute of Agricultural and Food Biotechnology, Poland), with 1 being related to minor and 4 to the greatest marbling. The taste panel of four professional assessors, trained in rating lamb for meat-eating quantity, was used to assess aroma, juiciness, tenderness, and flavor on boiled LT samples. Assessors scored the samples for each trait separately on a 1-5 point scale, where 1 was related to bad and 5 to a very good level of the traits according to the methodology of Barylko-Pikielna[21]. Concerning the abovementioned visual and sensory evaluations of meat, the mean values of the scores given by four assessors were taken for further calculations.

\section{Determination of phenolic acid, flavonoid, and diterpenoid contents}

Approximately $100 \mathrm{mg}$ of CAL ground to powder form was extracted three times with $80 \% \mathrm{methanol}(3 \mathrm{ml})$ for $60 \mathrm{~min}$ at $40^{\circ} \mathrm{C}$. The extracts were combined and evaporated to dryness, and then $20 \mathrm{mg}$ of this sample was dissolved in $3 \mathrm{ml}$ of Milli-Q water (acidified with $0.2 \%$ formic acid) and purified by solid phase extraction (SPE) using Oasis HLB 12cc Vac Cartridge, 500 mg (Waters, Milford, MA). The cartridges were washed with $0.5 \%$ methanol $(3 \mathrm{ml})$ to remove carbohydrates and then washed with $80 \%$ methanol ( 3 ml) to elute phenolics and diterpenes. Then obtained fraction $(2.5 \mathrm{mg}$ ) was re-evaporated and dissolved in $1 \mathrm{~mL}$ of $80 \%$ methanol (acidified with $0.2 \%$ formic acid). The sample was then centrifuged $(23,000 \times g$ for $5 \mathrm{~min})$ before undergoing spectrometric analysis. All analyses were performed in triplicate for three independent samples that were stored in a freezer at $-20^{\circ} \mathrm{C}$ before analysis.

The CAL compounds were analyzed on a UHRMS DionexUltiMate 3000RS system (Thermo Scientific, Darmstadt, Germany) with a charged aerosol detector interfaced with a high-resolution quadrupole time-of-flight mass spectrometer (HR/QTOF/MS, Compact, Bruker Daltonik, Bremen, Germany). The CAL phenolic acids, flavonoids, and diterpenes were chromatographically analyzed on a Kinetex C18 column (2.1 × 100 $\mathrm{mm}, 2.6 \mu \mathrm{m}$, Phenomenex, USA), with mobile phase A consisting of $0.1 \%(\mathrm{v} / \mathrm{v})$ FA in water and mobile phase B consisting of $0.1 \%$ ( $\mathrm{v} / \mathrm{v}$ ) FA in acetonitrile. A linear gradient from 7-50\% phase B in phase A over 20 min was used to separate phenolic compounds with a short 0.3 min calibration segment from 0 to $0.5 \mathrm{~min}$. injection $5 \mu \mathrm{l}$, a flow rate of $0.3 \mathrm{~mL} / \mathrm{min}$, and with the column held at $25^{\circ} \mathrm{C}$. Spectra were acquired in negative-ion and positive-ion modes over a mass range from m/z 100 to 1500 at $5 \mathrm{~Hz}$. The operating parameters of the ESI (Electro Spray Ionization) ion source were $3 \mathrm{kV}$ capillary voltage, $6 \mathrm{~L} / \mathrm{min}$ dry gas flow, $200^{\circ} \mathrm{C}$ dry gas temperature, 0.7 bar nebulizer pressure, $700.0 \mathrm{~V}$ collision radio frequency, $100.0 \mu$ s transfer time, and $7.0 \mu$ s prepulse storage. Ultrapure nitrogen was used as a drying and nebulizer gas, and argon was used as the collision gas. The collision energy was set automatically in the 15 to $75 \mathrm{eVi}$ range, depending on the $\mathrm{m} / \mathrm{z}$ of the fragmented ion. The readings were calibrated internally with sodium formate introduced to the ion source at the beginning of each separation via a $20 \mu \mathrm{L}$ loop. The spectra were processed using Bruker Data Analysis 4.3 software. (Bruker Daltonik, Bremen, Germany). The amounts of the individual phenolic acids in the CAL extract were calculated as equivalents of rosmarinic acid (CAS 537-15-5; (R)-rosmarinic acid, Sigma Aldrich) and flavonoids as equivalentsof isoquercetin (CAS 482-35-9; quercetin 3-0-glucopyranoside, Sigma Aldrich). Calibration curves for these two compounds were constructed based on seven concentration points (from 3.9 to $1000 \mu \mathrm{g} / \mathrm{ml}$ ). The amount of diterpenes in CAL was calculated as equivalents of carnosic acid (CAS 365009 - 7, Sigma Aldrich) at seven concentration points ( 0.05 to $125 \mu \mathrm{g} / \mathrm{ml})$. All analyses were performed in triplicate. The present analysis procedure on phenolics fraction was following previous published study [14].

\section{Determination of the chemical composition of feeds}

Samples of grass silage, concentrate, CAL, and feces were analyzed according to AOAC [22] for DM (method no. 934.01), ash (method no. 942.05), crude protein (CP; using a Kjel-Foss Automatic 16210 analyzer; method no. 976.05), and ether extract (EE, using a Soxhlet System HT analyzer; method no. 973.18). The organic matter (OM) content was calculated by subtracting ash concentration from DM content. The aNDFwas determined following the method of Van Soest et al. [23], with the addition of amylase and sodium sulfite without residual ash.

\section{Basic rumen fermentation analysis and $\mathrm{CH}_{4}$ measurement}

The $\mathrm{pH}$ of ruminal samples from all the experiments was measured immediately after samples collection using a pH meter (CP-104; Elmetron, Zabrze, Poland). The ammonia concentration was analyzed using the colorimetric Nessler method described earlier by [9]. The VFA profile was determined by gas chromatography (GC Varian CP 3380, Sugarland, TX, USA) following the protocol of Varadyova[24]. The in vitro $\mathrm{CH}_{4}$ 
concentration was measured using a gas chromatography in SRI PeakSimple model 310 (Alltech, PA, USA) following the procedure described by Kozlowskaet al.[25].

Methane production in the in vivo experiment was measured using two respiration chambers (SPA System, Wrocław, Poland). The total chamber volume $\left(8.2 \mathrm{~m}^{3}\right.$ ) was ventilated by recirculating fans set at $40 \mathrm{~m}^{3} / \mathrm{h}$ giving approximately 5 air changes per hour. The temperature and relative humidity were set at $16^{\circ} \mathrm{C}$ and $60 \%$, respectively. The concentrations of $\mathrm{CH}_{4}$ and $\mathrm{CO}_{2}$ weremeasured using two nondispersive infrared spectroscopy detectors operating in the near-infrared spectrum (Servomex 4100, Servomex, UK; 1210 Gfx detector). Measurements were taken at two-second intervals. Two measuring channels were used: the concentration of $\mathrm{CO}_{2}$ in the range of $0-2.5 \%\left(0-48,450 \mathrm{mg} / \mathrm{m}^{3}\right)$ and the $\mathrm{CH}_{4}$ concentration in the range of 0-1000 ppm $\left(0-706 \mathrm{mg} / \mathrm{m}^{3}\right)$. The sample was collected and then ducted to the analyzer via a polyethylene tube with a diameter of $8 \mathrm{~mm}$. The sampling rate was $0.6 \mathrm{~L} / \mathrm{min}$. Before starting the experiment, the analyzers were calibrated using as calibration gases (99.999\% nitrogen gas by volume, $1210 \mathrm{ppm} \mathrm{CH}_{4}$ in nitrogen, and $4680 \mathrm{ppm} \mathrm{CO}_{2}$ in nitrogen). The analyzer was equipped with a $0.17 \mathrm{~L}$ cuvette with an optical track of $540 \mathrm{~mm}$ for $\mathrm{CH}_{4}$ and a $0.012 \mathrm{~L}$ cuvette with an optical track length of $154 \mathrm{~mm} \mathrm{for} \mathrm{CO}_{2}$.

\section{Microbial quantification}

The protozoa population was quantified following the method described by Michalowski et al. [26]. Methanogen numbers were quantified by fluorescence in situ hybridization (FISH) technique, following the procedure of Jozefiak et al. [27], with some modifications. Briefly, $50 \mu \mathrm{L}$ of the rumen fluid was diluted with phosphate-buffered saline (PBS) and pipetted onto $0.22 \mu \mathrm{m}$ polycarbonate filters (Frisenette K02BP02500) and vacuumed (Vacuum KNF, VacuportNeuberg). After vacuuming, the filters were transferred onto cellulose disks for dehydration in an ethanol series (50\%, 80\%, and 90\%, 3 min each). To allow determination of optimal hybridization, a series of identical filters was prepared in each sample. The hybridizations were carried out in $50 \mu \mathrm{L}$ of hybridization buffer $(0.9 \mathrm{M} \mathrm{NaCl} ; 20 \mathrm{mM} \mathrm{Tris/HCl,} \mathrm{pH} \mathrm{7.2;0.01 \%} \mathrm{SDS)} \mathrm{containing}$ oligonucleotide probes of total methanogens (S-D-Arch-0915-a-A-20), r Methanomicrobiales (S-0-Mmic-1200-a-A-21) order and Methanobacteriales (SF-Mbac-0310-a-A-22) order [28]. After hybridization, the filters were washed with washing buffer (20 mM Tris/HCl, pH 7.2; $0.01 \%$ SDS; $5 \mathrm{mM}$ EDTA) for $20 \mathrm{~min}$ at $48^{\circ} \mathrm{C}$. The filters were rinsed gently in distilled water, air-dried, and mounted on object glasses with VectaShield anti-fading agent (Vector laboratories $\mathrm{H}$-1000), which contained 4,6-diamidino-2-phenylindole (DAPI). Filters were maintained at $4^{\circ} \mathrm{C}$ for one hour in the dark until they were visualized with an Axio Imager M2 microscope (Carl Zeiss Iberia, Madrid, Spain) to distinguish the total count of bacteria (DAPI) from other the methanogens in the rumen fluid.

For analysis of abundances of eight selected species and two genera of rumen bacteria in the in vivo experiments, metagenomic DNA was extracted from the ruminal content using a Mini Bead-Beater (BioSpec Products, Bartlesville, OK, USA) for cell lysis and DNA was purified (QIAamp DNA Stool Mini Kit; Qiagen, Hilden, Germany). The DNA concentration was measured using a NanoDrop 1000 spectrophotometer (Thermo Scientific, Wilmington, DE, USA). The DNA used in this experiment had an A260:A280 ratio higher than 1.8. Sequences of primers specific to the particular bacterial species or genera are presented in Table 3[29-36]. 
Table 3

The sequences of primers specific to the analyzed bacteria species.

\begin{tabular}{|c|c|c|}
\hline Species & Primer sequences & Reference \\
\hline \multirow[t]{2}{*}{ Streptococcus bovis } & F: "TTCCTAGAGATAGGAAGTTTCTTCGG" & [29] \\
\hline & R: "ATGATGGCAACTAACAATAGGGGT" & \\
\hline \multirow[t]{2}{*}{ Ruminococcusflavefaciens } & F:“CGAACGGAGATAATTTGAGTTTACTTAGG" & [30] \\
\hline & R: “CGGTCTCTGTATGTTATGAGGTATTACC" & \\
\hline \multirow[t]{2}{*}{ Ruminococcus albus } & F: “CCCTAAAAGCAGTCTTAGTTCG" & {$[31]$} \\
\hline & R: “CCTCCTTGCGGTTAGAACA“ & \\
\hline \multirow[t]{2}{*}{ Megasphaeraelsdenii } & F: "AGATGGGGACAACAGCTGGA" & {$[29]$} \\
\hline & R: "CGAAAGCTCCGAAGAGCCT" & \\
\hline \multirow[t]{2}{*}{ Prevotella spp. } & F: "GAAGGTCCCCCACATTG " & {$[29]$} \\
\hline & R:"CAATCGGAGTTCTTCGTG" & \\
\hline \multirow[t]{2}{*}{ Lactobacillus spp. } & F: "TATGGTAATTGTGTGNCAGCMGCCGCGGTAA" & {$[32]$} \\
\hline & R: "AGTCAGTCAGCCGGACTACHVGGGTWTCTAAT" & \\
\hline \multirow[t]{2}{*}{ Fibrobacter succinogenes } & F: “GTTCGGAATTACTGGGCGTAAA" & [33] \\
\hline & R: “CGCCTGCCCCTGAACTATC" & \\
\hline \multirow[t]{2}{*}{ Butyrivibrioproteoclasticus } & F: "TCCTAGTGTAGCGGTGAAATG" & {$[34]$} \\
\hline & R: "TTAGCGACGGCACTGAATGCCTA" & \\
\hline \multirow[t]{2}{*}{ Butyrivibriofibrisolvens } & F: "ACACACCGCCCGTCACA" & {$[35]$} \\
\hline & R: "TCCTTACGGTTGGGTCACAGA" & \\
\hline \multirow[t]{2}{*}{ Anaerovibriolipolytica } & F: "GAAATGGATTCTAGTGGCAAACG" & {$[36]$} \\
\hline & R:"ACATCGGTCATGCGACCAA" & \\
\hline
\end{tabular}

The specificity of primers (Table 3) was confirmed using the BLAST program in the GenBank Database. The starting DNA concentration was 25 $\mathrm{ng} / \mu \mathrm{l}$ and the quantification of each bacterial species DNA and total bacteria in the total rumen DNA was carried out using a QuantStudio 12 Flex PCR system (Life Technologies, Thermo Fisher Scientific, Waltham, MA, USA). The Power SYBR Green PCR Master Mix (Thermo Fisher Scientific, Waltham, MA, USA) was used for PCR amplification. The reaction mixture in $10 \mu$ of the final volume contained $4 \mu$ l of the $2 \times$ Mastermix, $25 \mathrm{ng}$ of template DNA and $0.5 \mathrm{M}$ of each primer. Amplification involved one cycle at $95^{\circ} \mathrm{C}$ for $10 \mathrm{~min}$ for initial denaturation, 45 cycles of $95^{\circ} \mathrm{C}$ for $15 \mathrm{~s}$ followed by annealing at temperatures depending upon the individual bacteria, and then at $60^{\circ} \mathrm{C}$ for $62 \mathrm{~s}$. The fluorescent product was detected in the last step of each cycle. To determine the specificity of amplification, an analysis of product melting was performed after a single amplification $\left(0.1^{\circ} \mathrm{C} \cdot \mathrm{s}^{-1}\right.$ increment from $65^{\circ} \mathrm{C}$ to $95^{\circ} \mathrm{C}$ with fluorescence collection at $0.1^{\circ} \mathrm{C}$ intervals). Additionally, product size was verified by gel electrophoresis of samples after the PCR run. Dilution of purified genomic DNA from control strains was used to construct species-specific calibration curves; then further, the calibration curve was used for calculation of the species-specific DNA concentration in total rumen DNA preparations (number of DNA copies). The relative abundances of DNA copy of each bacterial species was then calculated using the formula $2^{-\triangle \Delta C t}(R T A)$, where the total bacterial DNA level was used as a reference.

\section{Analysis of fatty acid in feed and meat samples}

The FA profiles of the grass silage, concentrate, CAL, rumen fluid, and LT muscle were analyzed following the procedure of Cieslak et al.[37], with some modifications. Sample hydrolysis was carried out in a closed system using screw-cap Teflon-stoppered tubes (Pyrex, $15 \mathrm{~mL}$ ). Three milliliters of $2 \mathrm{M} \mathrm{NaOH}$ was added to 100, 2500, 100, 10, and $500 \mathrm{mg}$ of grass silage, concentrate, CAL, rumen fluid, and meat samples, respectively. Hydrolysed samples were incubated on a block heater at $90^{\circ} \mathrm{C}$ for $40 \mathrm{~min}$. The samples were then extracted and esterified using $0.5 \mathrm{M} \mathrm{NaOH}$ in methanol and subsequently converted to fatty acid methyl esters (FAME) using boron trifluoride (Fluka). A gas chromatograph (GC Bruker 456-GC, USA) fitted with a flame ionization detector and a $100 \mathrm{~m}$ fused-silica capillary column (0.25 mm i.d.) coated with $0.25 \mu \mathrm{m}$ Agilent HP (Chrompack CP7420) were used. Hydrogen was used as the carrier gas at a flow rate of $1.3 \mathrm{~mL} / \mathrm{min}$. The injector and detector temperatures were set at $200^{\circ} \mathrm{C}$ and $250^{\circ} \mathrm{C}$, respectively. The oven was programmed as follows: initially $120^{\circ} \mathrm{C}$ for $7 \mathrm{~min}$, increasing at $7^{\circ} \mathrm{C} / \mathrm{min}$ to $140^{\circ} \mathrm{C}$, holding for $10 \mathrm{~min}$ and then increasing at $4^{\circ} \mathrm{C} / \mathrm{min}$ to $240^{\circ} \mathrm{C}$. One microliter sample volume was injected into the column. The fatty 
acids were identified based on their retention times and expressed as a g/100 $\mathrm{g}$ FA. The peaks were identified by comparison of the retention times with FAME standards (37 FAME Mix, Sigma Aldrich, PA, USA).

The conjugated linoleic acid (CLA) peaks were identified via comparison with the retention times of the reference standard (conjugated linoleic acid methyl esters, and a mixture of cis- and trans-9, -11 and - 10,12-octadecadienoic acid methyl esters; Sigma) using Galaxie Work Station 10.1 (Varian, CA, USA). The desaturase index, atherogenic index, and thrombogenic index were calculated as described by Bryszak et al. [9].

\section{Analysis of mRNA expression in meat samples}

Transcript analysis of FADS1, FASN, LPL, SCD, and ELOVL5 genes in the meat samples was performed using quantitative PCR (qPCR) analysis. Total RNA was isolated from 100 mg of LT muscle using Extrazol reagent. In brief, the meat samples were homogenized in 0.5 ml of Extrazol reagent using a TissueLyser II (Qiagen, USA). After $10 \mathrm{~min}$ incubation, $200 \mu \mathrm{l}$ of chloroform was added and shaken vigorously for $15 \mathrm{~s}$. The samples were then incubated for $10 \mathrm{~min}$ at room temperature and centrifuged for $15 \mathrm{~min}$ at $12,000 \times \mathrm{g}$. Next, the upper aqueous phase was transferred to a new tube and $0.5 \mathrm{ml}$ of isopropanol was added. The samples were again incubated and centrifuged as in the previous step. The resulting RNA pellet was washed with $1 \mathrm{ml}$ of $75 \% \mathrm{EtOH}$ and dissolved in RNAse free water (Sigma Aldrich). The quantity and quality of the isolated total RNA was checked using an NP80 NanoPhotometer (Implen, Germany). A reverse transcription reaction (RT) was carried out with 1 $\mu \mathrm{g}$ of total RNA and the Firescript RT cDNA Synthesis MIX with Oligo (dT) and Random primers (Solis BioDyne), following the manufacturer's protocol. The mRNA expression was quantified using QuantStudio 12 Flex PCR system (Life Technologies, Thermo Fisher Scientific, Waltham, MA, USA) and SYBR Green PCR Master Mix (Thermo Fisher Scientific, Waltham, MA, USA). The primer pairs used for RT-qPCR amplification are listed in Table 4[38]. The specificity of reaction products was determined by the melting points $(0.1 \mathrm{C} / \mathrm{s}$ transition rate). Two genes have been considered as reference, GAPDH and $\beta$-actin. Due to its higher stability, the $\beta$-actin gene was applied and relative mRNA expression was evaluated by delta-delta $\mathrm{CT}(\triangle \triangle \mathrm{CT})$.

Table 4

The sequences of primers specific to the analyzed genes expression in the lamb's LTmuscle.

\begin{tabular}{|c|c|c|c|}
\hline \multirow[t]{2}{*}{ Gene name } & \multicolumn{2}{|l|}{ Primer sequence (5区 to $3 \rrbracket$ ) } & \multirow[t]{2}{*}{ Reference } \\
\hline & Forward & Reverse & \\
\hline$S C D$ & GAGTACCGCTGGCACATCAA & CTAAGACGGCAGCCTTGGAT & [38] \\
\hline ELOVL5 & TGCTTCAGTTTGTGCTGACC & TGGTCCTTCTGGTGCTCTCT & [38] \\
\hline FASN & GGAGGACGCTTTCCGTTACA & TGCTCTTCСTCACGTACCTGAA & [38] \\
\hline FADS1 & CTGCTGTACCTGCTGCACAT & ACGGACAGGTGTCCAAAGTC & {$[38]$} \\
\hline$L P L$ & TCATCGTGGTGGACTGGCT & CATCCGCCATCCAGTTCATA & [38] \\
\hline
\end{tabular}

\section{Statistical analysis}

The data of the experiment 1 (RUSITEC) were analyzed using a mixed model procedure (PROC MIXED) in SAS (University edition, version 9.4; SAS Institute, Cary, NC, USA) with repeated measures of day and fermenter treated as the experimental unit. The dietary treatment was considered as the fixed effect, experimental run as the random effect, and the day (6 to 10 days) as the repeated factor. Differences among treatments were further determined using Tukey's post hoc test and linear orthogonal contrast was used to ascertain the tendency of the dose effect of CAL. In experiment 2, data were analyzed using PROC MIXED of SAS with the model containing dietary group, hour, and their interaction (group $\times$ hour) as the fixed effects and the animal and hour of sample collection as the random effect with repeated measures. When the significant value of the interaction occurred, Tukey's post hoc test was used to estimate the differences between means. In experiment 3, data were analyzed using PROC TTEST procedure of SAS, and for all parameters each animal was considered as the experimental unit. Significance was accepted at $P<0.05$ and tended to significance at $0.05<\mathrm{P}<0.10$. All the values are shown as group means with pooled standard errors of means.

\section{Results}

\section{Nutrients and phytochemical composition of CAL}

The CAL had higher CP, EE, and ash concentrations than the concentrate and grass silage (Table 1). It also had relatively higher PUFA proportion, especially of n-3 FA, mainly due to the high content of C18:3 cis-9, cis-12, cis-15. The CAL contained $20.24 \mathrm{mg} / \mathrm{g}$ DM of total polyphenolic compounds and diterpenes, at $19.6 \mathrm{mg} / \mathrm{g}$ DM. Among the various diterpenes present in CAL, acetoxy dihydroxy royleanone had

Page $10 / 29$ 
the highest concentration at $13.4 \mathrm{mg} / \mathrm{g}$ DM. The CAL also contained high amounts of dihydroxyroyleanone $4.77 \mathrm{mg} / \mathrm{g}$ DM. Among the polyphenols, luteolin-O-glucuronide was present at $4.34 \mathrm{mg} / \mathrm{g} \mathrm{DM}$, rosmarinic acid at $3.35 \mathrm{mg} / \mathrm{g} \mathrm{DM}$, and caffeic acid at $3.19 \mathrm{mg} / \mathrm{g}$ DM (Table 2).

\section{In vitro experiment (Experiment 1)}

Increased supplementation with CAL did not alter the basic ruminal fermentation parameters, such as pH and concentrations ofammonia or total VFA (Table 5). However, the molar proportions of acetate, propionate, butyrate, isovalerate, and valerate were dose-dependent. The proportions of acetate and isovalerate were lower in the $15 \%$ and $20 \%$ CAL treatments $(P \leq 0.05)$, but the proportions of butyrate and valerate were higher in the CAL diets than in CON $(P \leq 0.02)$. A linearly lower $(P<0.01) A / P$ ratio was observed with increasing CAL. Digestibility of $D M$, OM, and NDF was unaffected by CAL, but a higher crude protein digestibility was noted for the $10 \%$ and $20 \%$ CAL supplementation with a linear response $(P=0.03)$. Total gas and $\mathrm{CH}_{4}$ production $(\mathrm{ml}$ or $\mathrm{ml} / \mathrm{g} \mathrm{DN})$ decreased linearly $(P \leq 0.01)$ with increasing levels of $\mathrm{CAL}$ in diets. Protozoa counts were unaffected by the inclusion of CAL (Table 6). The 10\% CAL addition increased the populations of Streptococcus bovis, Prevotellaspp.,Butyrivibrioproteoclasticus, andButyrivibriofibrisolvens( $\mathrm{P} \leq 0.02)$. The CAL treatments linearly decreased the total Archaea and Methanobacteriales population $(\mathrm{P}<0.01)$. 
Table 5

The effect of CAL on in vitro ruminal fermentation and methane production (Experiment 1).

\begin{tabular}{|c|c|c|c|c|c|c|c|}
\hline \multirow[t]{2}{*}{ Parameters } & \multirow[t]{2}{*}{ CON } & \multicolumn{3}{|c|}{ CAL (\% in diet) } & \multirow[t]{2}{*}{ SEM } & \multicolumn{2}{|c|}{$P$ value } \\
\hline & & 10 & 15 & 20 & & Diet & $\mathrm{L}$ \\
\hline \multicolumn{8}{|l|}{ Rumenfermentation } \\
\hline Redoxpotential, mV & -335 & -336 & -329 & -333 & 2.11 & 0.35 & 0.34 \\
\hline $\mathrm{pH}$ & 6.89 & 6.89 & 6.91 & 6.91 & 0.001 & 0.12 & 0.08 \\
\hline $\mathrm{NH}_{3}, \mathrm{mM}$ & 9.19 & 9.19 & 9.11 & 9.18 & 0.25 & 0.99 & 0.96 \\
\hline Total VFA, mM & 44.7 & 44.4 & 44.6 & 47.1 & 1.15 & 0.62 & 0.36 \\
\hline \multicolumn{8}{|l|}{ VFA, molarpercent } \\
\hline Acetate (A) & $61.3^{a}$ & $59.7^{a b}$ & $58.2^{b}$ & $56.9^{c}$ & 0.74 & 0.01 & $<0.01$ \\
\hline Propionate (P) & $22.9^{b c}$ & $22.7^{c}$ & $23.7^{a b}$ & $24.7^{a}$ & 0.37 & $<0.01$ & $<0.01$ \\
\hline Isobutyrate & 3.36 & 3.56 & 3.57 & 3.62 & 0.17 & 0.78 & 0.35 \\
\hline Butyrate & $8.19^{b}$ & $9.10^{a}$ & $9.36^{a}$ & $9.36^{a}$ & 0.14 & 0.02 & $<0.01$ \\
\hline Isovalerate & $1.01^{a b}$ & $1.12^{a}$ & $0.91^{b}$ & $0.93^{b}$ & 0.03 & 0.04 & 0.13 \\
\hline Valerate & $3.01^{c}$ & $3.76^{b}$ & $4.15^{a b}$ & $4.22^{a}$ & 0.14 & $<0.01$ & $<0.01$ \\
\hline $\mathrm{A} / \mathrm{P}$ ratio & $2.75^{a}$ & $2.69^{a}$ & $2.51^{b}$ & $2.35^{b}$ & 0.07 & $<0.01$ & $<0.01$ \\
\hline \multicolumn{8}{|l|}{ Digestibility, g/kg DM } \\
\hline Drymatter & 505 & 526 & 499 & 518 & 6.40 & 0.38 & 0.78 \\
\hline Organicmatter & 516 & 530 & 504 & 524 & 6.36 & 0.47 & 0.99 \\
\hline Crude protein & $430^{b}$ & $489^{a}$ & $453^{a b}$ & $489^{a}$ & 7.82 & 0.01 & 0.03 \\
\hline Neutral detergent fiber & 491 & 506 & 483 & 488 & 7.11 & 0.66 & 0.59 \\
\hline \multicolumn{8}{|c|}{ Total gas and methane emission } \\
\hline Gas, mL & $2902^{a}$ & $2984^{a}$ & $2920^{a}$ & $2534^{b}$ & 51.0 & $<0.01$ & 0.01 \\
\hline Gas, mL/g DM & $264^{a}$ & $271^{a}$ & $265^{a}$ & $230^{b}$ & 4.63 & $<0.01$ & 0.01 \\
\hline $\mathrm{CH}_{4}, \mathrm{~mL}$ & $92.0^{a}$ & $79.0^{a b}$ & $71.1^{b}$ & $46.6^{c}$ & 3.84 & $<0.01$ & $<0.01$ \\
\hline $\mathrm{CH}_{4}, \mathrm{~mL} / \mathrm{g} \mathrm{DM}$ & $8.64^{a}$ & $7.41^{a b}$ & $6.45^{b}$ & $4.22^{c}$ & 0.34 & $<0.01$ & $<0.01$ \\
\hline $\mathrm{CH}_{4}, \mathrm{~mL} / \mathrm{L}$ gas & $33.6^{a}$ & $28.3^{a b}$ & $24.2^{b}$ & $18.2^{c}$ & 1.24 & $<0.01$ & $<0.01$ \\
\hline $\mathrm{CH}_{4}, \mathrm{~mL} / \mathrm{g} \mathrm{DMD}$ & $17.1^{a}$ & $14.0^{a}$ & $14.9^{a}$ & $8.61^{b}$ & 0.70 & $<0.01$ & $<0.01$ \\
\hline \multicolumn{8}{|c|}{$\begin{array}{l}\text { CON: Control diet; CAL: Coleus amboinicus Lour. herb diet; SEM: standard error of means; L: linear response; } \mathrm{DM} \text { : dry matter; } \mathrm{NH}_{3} \text { : ammoni } \\
\text { VFA: volatile fatty acid; } \mathrm{CH}_{4} \text { : methane; DMD, dry matter digestibility. }\end{array}$} \\
\hline
\end{tabular}


Table 6

The effect of CAL on in vitro ruminal microorganisms (Experiment 1)

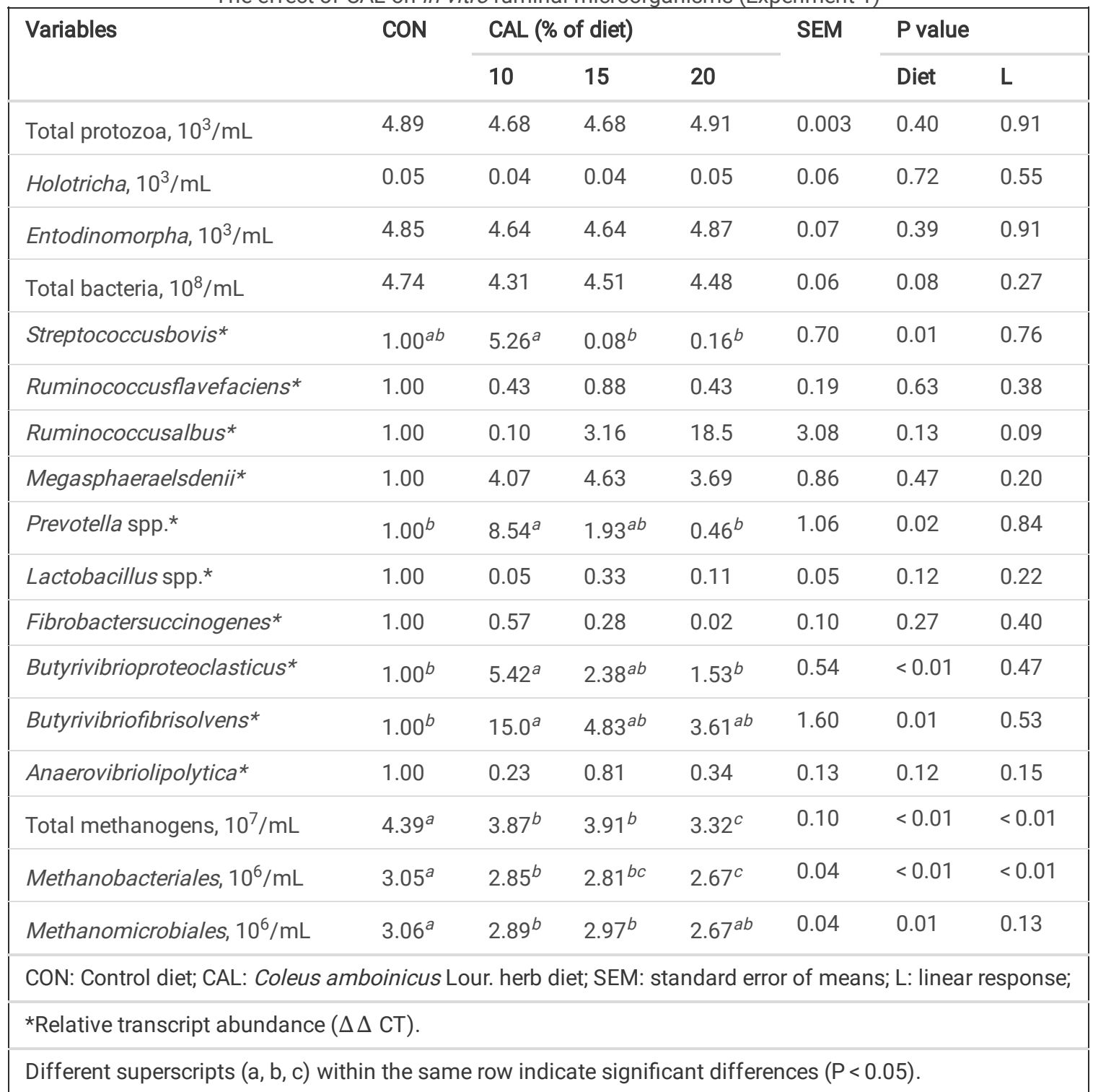

The FA proportions in the ruminal fluid were altered by CAL supplementation (Table 7). The C18:0, C18:1 trans-10, C18:1 trans-11, total C18:1 trans, $\mathrm{C} 20: 1$ trans, decreased linearly with increasing levels of CALin the diets ( $\leq \leq 0.05)$. The C18:1 cis-9, C18:1 cis-11, C24:1, C18:2 cis-12 trans10 (CLA), C18:2 cis-9 cis-12 (linoleic acids; LA), PUFA, andn-6 FA proportions in CAL treatments increased linearly (P $\leq 0.05$ ). The CAL treatments had a lower total SFA and higher total UFA proportion in ruminal fluid, and both were altered in a linear manner ( $<<0.01)$. Also, the total $\mathrm{BH}$ intermediates, $\mathrm{LA}-\mathrm{BH}$ and LNA-BH were decreased by CAL with a linear response $(\mathrm{P}<0.01)$. The $\mathrm{C} 18: 3$ cis-9 cis-12 cis-15, $\mathrm{n}-3 \mathrm{FA}$, total CLA, PUFA/SFA and LNA/LA proportions were higher at $20 \%$ CAL supplementation $(P \leq 0.05)$ than the CON. 
Table 7

The effect of CALon in vitroruminal FA composition (Experiment 1)

\begin{tabular}{|c|c|c|c|c|c|c|c|}
\hline \multirow[t]{2}{*}{ Fatty acid, $\%$ of total FA } & \multirow[t]{2}{*}{ CON } & \multicolumn{3}{|l|}{ CAL } & \multirow[t]{2}{*}{ SEM } & \multicolumn{2}{|c|}{$P$ value } \\
\hline & & 10 & 15 & 20 & & Diet & $L$ \\
\hline \multicolumn{8}{|l|}{ Saturated FA } \\
\hline C10:0 & 0.26 & 0.31 & 0.30 & 0.28 & 0.02 & 0.84 & 0.77 \\
\hline C12:0 & 1.33 & 1.30 & 1.62 & 1.42 & 0.07 & 0.28 & 0.29 \\
\hline C14:0 & 1.53 & 1.51 & 1.51 & 1.47 & 0.04 & 0.94 & 0.56 \\
\hline C15:0 & 1.14 & 1.13 & 1.10 & 1.09 & 0.03 & 0.91 & 0.49 \\
\hline $\mathrm{C} 16: 0$ & 21.2 & 21.3 & 21.7 & 20.9 & 0.20 & 0.48 & 0.89 \\
\hline $\mathrm{C} 17: 0$ & 0.76 & 0.72 & 0.72 & 0.72 & 0.02 & 0.78 & 0.39 \\
\hline C18:0 & $41.0^{a}$ & $36.7^{b}$ & $36.5^{b}$ & $33.8^{b}$ & 0.77 & $<0.01$ & $<0.01$ \\
\hline $\mathrm{C} 20: 0$ & 0.07 & 0.09 & 0.08 & 0.06 & 0.01 & 0.63 & 0.54 \\
\hline $\mathrm{C} 21: 0$ & 0.20 & 0.21 & 0.18 & 0.19 & 0.02 & 0.95 & 0.77 \\
\hline $\mathrm{C} 22: 0$ & 0.13 & 0.16 & 0.16 & 0.18 & 0.01 & 0.46 & 0.13 \\
\hline C23:0 & 0.17 & 0.16 & 0.14 & 0.15 & 0.01 & 0.82 & 0.43 \\
\hline $\mathrm{C} 24: 0$ & 0.52 & 0.46 & 0.45 & 0.44 & 0.02 & 0.17 & 0.04 \\
\hline \multicolumn{8}{|l|}{ Monounsaturated FA } \\
\hline C14:1 & 0.50 & 0.48 & 0.37 & 0.38 & 0.03 & 0.12 & 0.04 \\
\hline C15:1 & 0.52 & 0.62 & 0.55 & 0.60 & 0.03 & 0.69 & 0.57 \\
\hline C16:1 & 0.57 & 0.77 & 0.61 & 0.89 & 0.06 & 0.16 & 0.11 \\
\hline C17:1 & 0.21 & 0.23 & 0.25 & 0.24 & 0.02 & 0.90 & 0.47 \\
\hline C18:1 trans-10 & $1.01^{a}$ & $0.80^{a b}$ & $0.65^{b}$ & $0.57^{b}$ & 0.06 & 0.05 & $<0.01$ \\
\hline C18:1 trans-11 (VA) & $2.40^{a}$ & $1.84^{b}$ & $1.86^{b}$ & $1.67^{b}$ & 0.08 & $<0.01$ & $<0.01$ \\
\hline C18:1 cis-9 & $10.9^{b}$ & $12.9^{a}$ & $13.8^{a}$ & $13.7^{a}$ & 0.37 & 0.02 & $<0.01$ \\
\hline C18:1 cis-11 & $1.14^{b}$ & $1.26^{a b}$ & $1.33^{a}$ & $1.31^{a}$ & 0.03 & 0.03 & $<0.01$ \\
\hline C18:1 cis-12 & 0.14 & 0.14 & 0.11 & 0.12 & 0.01 & 0.68 & 0.37 \\
\hline C18:1 cis-13 & 0.20 & 0.14 & 0.09 & 0.14 & 0.02 & 0.11 & 0.09 \\
\hline C18:1 cis-14 & 0.33 & 0.36 & 0.37 & 0.37 & 0.02 & 0.85 & 0.42 \\
\hline C20:1 trans & $0.95^{a}$ & $0.89^{a b}$ & $0.87^{a b}$ & $0.81^{b}$ & 0.02 & 0.05 & $<0.01$ \\
\hline C24:1 & $0.15^{b}$ & $0.16^{b}$ & $0.27^{a}$ & $0.28^{a}$ & 0.02 & $<0.01$ & 0.03 \\
\hline \multicolumn{8}{|l|}{ Polyunsaturated FA } \\
\hline C18:2 cis-12 trans-10 & $0.23^{b}$ & $0.30^{a}$ & $0.23^{b}$ & $0.32^{a}$ & 0.01 & $<0.01$ & 0.04 \\
\hline C18:2 cis-9 trans-11 (RA) & 0.09 & 0.12 & 0.13 & 0.09 & 0.01 & 0.45 & 0.99 \\
\hline C18:2 cis-9 cis-12 (LA) & $10.5^{b}$ & $12.6^{a}$ & $12.3^{a}$ & $13.0^{a}$ & 0.35 & 0.04 & 0.02 \\
\hline
\end{tabular}

CON: Control diet; CAL: Coleus amboinicus Lour. herb diet; SEM: standard error of means; L: linear response; VA, vaccenic acid; RA, rumenic acid; SFA, saturated fatty acids; MUFA, monounsaturated fatty acids; PUFA, polyunsaturated fatty acids; LA, linoleic acid; MCFA, mediumchain fatty acids; LCFA, long-chain fatty acids; BH int, biohydrogenation intermediates; CLA, conjugated linoleic acids; LA BH,

biohydrogenation of linoleic acid; LNA BH, biohydrogenation of linolenic acid.

Different superscripts $(a, b, c)$ within the same row indicate significant differences at $P<0.05$ and tended to significant at $P<0.10$. 


\begin{tabular}{|c|c|c|c|c|c|c|c|}
\hline \multirow[t]{2}{*}{ Fatty acid, $\%$ of total FA } & \multirow[t]{2}{*}{ CON } & \multicolumn{3}{|l|}{ CAL } & \multirow[t]{2}{*}{ SEM } & \multicolumn{2}{|c|}{$P$ value } \\
\hline & & 10 & 15 & 20 & & Diet & $\mathrm{L}$ \\
\hline C18:3 cis-6 cis-9 cis-12 & 0.12 & 0.09 & 0.10 & 0.11 & 0.01 & 0.43 & 0.84 \\
\hline C18:3 cis-9cis-12cis-15 (LNA) & $1.25^{b}$ & $1.79^{a b}$ & $1.59^{a b}$ & $4.10^{a}$ & 0.35 & 0.01 & $<0.01$ \\
\hline $\mathrm{C} 20: 2$ & 0.32 & 0.31 & 0.32 & 0.28 & 0.03 & 0.96 & 0.72 \\
\hline $\mathrm{C} 22: 2$ & 0.12 & 0.09 & 0.10 & 0.11 & 0.01 & 0.65 & 0.75 \\
\hline$\sum$ SFA & $68.3^{a}$ & $64.1^{b}$ & $64.4^{b}$ & $60.7^{c}$ & 0.79 & $<0.01$ & $<0.01$ \\
\hline$\sum$ UFA & $31.7^{a}$ & $35.9^{b}$ & $35.6^{b}$ & $39.2^{c}$ & 0.79 & $<0.01$ & $<0.01$ \\
\hline$\sum$ MUFA & 19.0 & 20.6 & 20.8 & 21.2 & 0.38 & 0.15 & 0.04 \\
\hline$\sum$ PUFA & $12.6^{c}$ & $15.3^{b}$ & $14.8^{b c}$ & $17.9^{a}$ & 0.55 & $<0.01$ & $<0.01$ \\
\hline$\sum n-6$ & $11.1^{b}$ & $13.1^{a}$ & $12.8^{a b}$ & $13.5^{a}$ & 0.35 & 0.04 & 0.02 \\
\hline$\sum n-3$ & $1.25^{b}$ & $1.79^{b}$ & $1.59^{b}$ & $4.10^{a}$ & 0.35 & 0.01 & $<0.01$ \\
\hline$n-6 / n-3$ & 9.11 & 8.75 & 8.98 & 6.94 & 0.44 & 0.26 & 0.11 \\
\hline PUFA/SFA & $0.19^{b}$ & $0.25^{b}$ & $0.23^{b}$ & $0.31^{a}$ & 0.01 & $<0.01$ & $<0.01$ \\
\hline LNA/LA & $0.12^{b}$ & $0.14^{b}$ & $0.13^{b}$ & $0.31^{a}$ & 0.03 & 0.01 & $<0.01$ \\
\hline$\sum \mathrm{C} 18: 1$ & 16.0 & 17.5 & 17.9 & 17.9 & 0.38 & 0.21 & 0.06 \\
\hline$\sum \mathrm{C} 18: 1$ trans- & $3.33^{a}$ & $2.50^{b}$ & $2.59^{b}$ & $2.28^{b}$ & 0.09 & $<0.01$ & $<0.01$ \\
\hline$\sum \mathrm{C} 18: 1$ cis- & $12.8^{b}$ & $15.0^{a}$ & $15.3^{a}$ & $15.7^{a}$ & 0.40 & 0.03 & $<0.01$ \\
\hline$\sum \mathrm{CLA}$ & $0.32^{b}$ & $0.42^{a}$ & $0.36^{a b}$ & $0.41^{a}$ & 0.02 & 0.05 & 0.11 \\
\hline$\sum$ MCFA & 27.0 & 27.4 & 27.8 & 27.1 & 0.27 & 0.69 & 0.83 \\
\hline$\sum$ LCFA & 73.0 & 72.6 & 72.2 & 72.8 & 0.27 & 0.72 & 0.69 \\
\hline $\mathrm{BH}$ Int & $4.31^{a}$ & $3.57^{b}$ & $3.52^{b}$ & $3.31^{b}$ & 0.10 & $<0.01$ & $<0.01$ \\
\hline LA BH (\%) & $64.6^{a}$ & $57.2^{b}$ & $56.1^{b}$ & $53.6^{b}$ & 1.26 & $<0.01$ & $<0.01$ \\
\hline LNA BH (\%) & $94.2^{a}$ & $92.0^{a}$ & $91.5^{a}$ & $78.1^{b}$ & 1.88 & $<0.01$ & $<0.01$ \\
\hline RA/VA & 0.05 & 0.08 & 0.07 & 0.07 & 0.01 & 0.24 & 0.44 \\
\hline \multicolumn{8}{|c|}{$\begin{array}{l}\text { CON: Control diet; CAL: Coleus amboinicus Lour. herb diet; SEM: standard error of means; L: linear response; VA, vaccenic acid; RA, rumen } \\
\text { acid; SFA, saturated fatty acids; MUFA, monounsaturated fatty acids; PUFA, polyunsaturated fatty acids; LA, linoleic acid; MCFA, medium- } \\
\text { chain fatty acids; LCFA, long-chain fatty acids;BH int, biohydrogenation intermediates; CLA, conjugated linoleic acids; LA BH, } \\
\text { biohydrogenation of linoleic acid; LNA BH, biohydrogenation of linolenic acid. }\end{array}$} \\
\hline Different superscripts $(a, b, c)$ & $v$ ind & gnificar & nces & 05 an & to & ant at & \\
\hline
\end{tabular}

In vivo experiment

In Experiment 2, ruminal pH and ammonia concentration in cannulated lambs fed the CAL diet was higher than in the CON group $(P<0.01)$, and these variables were post-feeding time dependent $(P<0.01$; Table 8). The total VFA concentration was similar in both diets and was timedependent $(P<0.01)$. Butyrate, isovalerate, and valerate proportions decreased when CAL treatment was used $(P<0.01)$. Time-dependent variation was observed in almost all the individual VFA proportions. The ratio of acetate to propionate (A/P) decreased in both diet- and timedependent manners $(P<0.01)$. 
Table 8

The effect of CALon ruminal fermentation in cannulated lambs (Experiment 2).

\begin{tabular}{|c|c|c|c|c|c|c|c|c|c|c|c|c|c|c|c|}
\hline \multirow[t]{2}{*}{ Parameter } & \multicolumn{3}{|l|}{$\mathrm{Oh}$} & \multicolumn{3}{|l|}{$3 \mathrm{~h}$} & \multicolumn{3}{|l|}{$6 \mathrm{~h}$} & \multicolumn{2}{|c|}{ Group } & \multirow[t]{2}{*}{ SEM } & \multicolumn{3}{|c|}{$P$ value } \\
\hline & CON & CAL & SEM & CON & CAL & SEM & CON & CAL & SEM & CON & CAL & & G & $\mathrm{H}$ & GxH \\
\hline $\mathrm{pH}$ & 6.87 & 7.05 & 0.09 & 5.95 & 6.39 & 0.06 & 6.34 & 6.58 & 0.04 & 6.39 & 6.67 & 0.05 & $\dot{0} 01$ & $\begin{array}{l}< \\
0.01\end{array}$ & 0.20 \\
\hline $\mathrm{NH}_{3}, \mathrm{mM}$ & 8.75 & 10.4 & 0.33 & 9.34 & 11.2 & 0.45 & 5.85 & 8.93 & 0.57 & 7.98 & 10.2 & 0.30 & $\begin{array}{l}< \\
0.01\end{array}$ & $\begin{array}{l}< \\
0.01\end{array}$ & 0.27 \\
\hline $\begin{array}{l}\text { Total VFA, } \\
\mathrm{mM}\end{array}$ & 66.8 & 67.9 & 2.77 & 103.6 & 101.3 & 3.83 & 83.4 & 86.9 & 1.50 & 84.6 & 85.4 & 2.36 & 0.79 & $\begin{array}{l}< \\
0.01\end{array}$ & 0.73 \\
\hline \multicolumn{16}{|c|}{$\begin{array}{l}\text { VFA, } \\
\text { molarpercent }\end{array}$} \\
\hline Acetate (A) & 71.6 & 69.8 & 0.39 & 66.2 & 66.4 & 0.41 & 67.4 & 67.7 & 0.44 & 68.4 & 67.9 & 0.32 & 0.29 & $\begin{array}{l}< \\
0.01\end{array}$ & 0.08 \\
\hline $\begin{array}{l}\text { Propionate } \\
\text { (P) }\end{array}$ & $\begin{array}{l}15.6 \\
d\end{array}$ & $17.5^{c}$ & 0.34 & $\begin{array}{l}16.3 \\
d\end{array}$ & $20.1^{a}$ & 0.49 & $15.7^{d}$ & $18.9^{\mathrm{b}}$ & 0.39 & 15.9 & 18.8 & 0.25 & $\begin{array}{l}< \\
0.01\end{array}$ & $\begin{array}{l}< \\
0.01\end{array}$ & 0.04 \\
\hline Isobutyrate & 0.42 & 0.61 & 0.07 & 0.52 & 0.93 & 0.10 & 0.46 & 0.76 & 0.07 & 0.47 & 0.77 & 0.05 & $\begin{array}{l}< \\
0.01\end{array}$ & 0.15 & 0.61 \\
\hline Butyrate & $10.3^{b}$ & $10.5^{b}$ & 0.11 & $14.9^{a}$ & $11.1^{\mathrm{b}}$ & 0.50 & $14.4^{\mathrm{a}}$ & $11.2^{\mathrm{b}}$ & 0.51 & 13.2 & 11.0 & 0.28 & $\begin{array}{l}< \\
0.01\end{array}$ & $\begin{array}{l}< \\
0.01\end{array}$ & $\begin{array}{l}< \\
0.01\end{array}$ \\
\hline Isovalerate & 1.00 & 0.75 & 0.05 & 0.53 & 0.41 & 0.02 & 0.62 & 0.44 & 0.03 & 0.72 & 0.53 & 0.03 & $\begin{array}{l}< \\
0.01\end{array}$ & $\begin{array}{l}< \\
0.01\end{array}$ & 0.31 \\
\hline Valerate & $1.11^{\mathrm{c}}$ & $0.92^{d}$ & 0.04 & $1.59^{a}$ & $1.07^{\mathrm{cd}}$ & 0.07 & $1.36^{\mathrm{b}}$ & $1.03^{\mathrm{cd}}$ & 0.07 & 1.36 & 1.01 & 0.04 & $<0.01$ & $\begin{array}{l}< \\
0.01\end{array}$ & 0.01 \\
\hline $\mathrm{A} / \mathrm{P}$ ratio & 4.61 & 4.04 & 0.11 & 4.07 & 3.33 & 0.10 & 4.29 & 3.61 & 0.09 & 4.33 & 3.66 & 0.06 & $\begin{array}{l}< \\
0.01\end{array}$ & $\begin{array}{l}< \\
0.01\end{array}$ & 0.71 \\
\hline
\end{tabular}

CON: Control diet; CAL: Coleus amboinicus Lour. herb diet; SEM: standard error of means. D: diet; H: hour; VFA: volatile fatty acids.

Means of different groups in the same row indicate significant differences at $\mathrm{P}<0.05$ and tended to significant at $\mathrm{P}<0.10$.

Holotricha had a lower population in the CAL group than in the CON group $(\mathrm{P}=0.02 ;$ Table 9$)$. Entodiniomorpha and total protozoa tended to increase $(P=0.07 ; P=0.06$, respectively) due to CAL supplementation. The CAL diet tended to increase total bacteria abundance $(P=0.09$, Table 9). The abundances of total methanogens, Methanobacteriales and Methanomicrobiales populations were decreased by the CAL diet ( $\mathrm{P}$ $\leq 0.04)$.

Table 9

The effect of CALon ruminal microbial populations in cannulated lambs (Experiment 2)

\begin{tabular}{|llccc|}
\hline Parameters & Control & CAL & SEM & P value \\
\hline Total protozoa, $10^{5} / \mathrm{mL}$ & 4.43 & 5.76 & 0.42 & 0.06 \\
\hline Holotricha, $10^{5} / \mathrm{mL}$ & 0.08 & 0.04 & 0.01 & 0.02 \\
\hline Entodiniomorpha, $10^{5} / \mathrm{mL}$ & 4.35 & 5.72 & 0.42 & 0.07 \\
\hline Total bacteria, $10^{9} / \mathrm{mL}$ & 4.12 & 4.37 & 0.07 & 0.09 \\
\hline Total methanogens, $10^{8} / \mathrm{mL}$ & 5.34 & 4.17 & 0.18 & $<0.01$ \\
\hline Methanobacteriales, $10^{7} / \mathrm{mL}$ & 4.20 & 3.03 & 0.16 & $<0.01$ \\
\hline Methanomicrobiales, $10^{7} / \mathrm{mL}$ & 3.35 & 2.97 & 0.09 & 0.04 \\
\hline CON: Control diet; CAL: Coleus amboinicus Lour. herb diet; SEM: standard error of means.
\end{tabular}

In Experiment 3, the CAL diet did not affect animal performance or digestibility (Table 10); but it significantly lowered the $\mathrm{CH}_{4}$ production of the lambs, expressed as a L/day, L/kg DMI, L/kg OM $(\mathrm{P}<0.01)$, and $\mathrm{CH}_{4} / \mathrm{BW}(\mathrm{P}=0.02)$. The $\mathrm{pH}$ value was higher $(\mathrm{P}=0.05)$ and ammonia concentration tended to increase $(P=0.09)$, when the CAL diet was used. Total VFA concentration did not change, but the propionate proportion 
was higher $(P=0.01)$ in the CAL group than in CON group. The concentrations of isovalerate and valerate as well as the $A / P$ ratio were lower $(P$ $\leq 0.04$ ) in CAL group than the CON group.

Table 10

Impact of CALon performance, methane emission, and ruminal fermentation of lambs (Experiment 3).

\begin{tabular}{|c|c|c|c|c|}
\hline Parameters & CON & CAL & SEM & $P$ value \\
\hline \multicolumn{5}{|l|}{ Body weight } \\
\hline Inital BW, kg & 19.3 & 19.7 & 0.66 & 0.70 \\
\hline Final BW, kg & 25.1 & 26.8 & 0.53 & 0.13 \\
\hline$A D G, g / d$ & 167 & 196 & 9.45 & 0.14 \\
\hline \multicolumn{5}{|l|}{ Total tractdigestibility } \\
\hline Drymatter, g/kg & 630 & 649 & 8.27 & 0.26 \\
\hline Organicmatter, g/kg & 607 & 604 & 6.80 & 0.82 \\
\hline Crude protein, g/kg & 604 & 601 & 7.71 & 0.85 \\
\hline Neutral detergent fiber, $\mathrm{g} / \mathrm{kg}$ & 577 & 578 & 13.3 & 0.97 \\
\hline \multicolumn{5}{|l|}{ Methaneemission } \\
\hline $\mathrm{CH}_{4}, \mathrm{~L} / \mathrm{d}$ & 20.0 & 15.9 & 0.11 & $<0.01$ \\
\hline $\mathrm{CO}_{2}, \mathrm{~L} / \mathrm{d}$ & 307 & 274 & 2.24 & $<0.01$ \\
\hline $\mathrm{CH}_{4} / \mathrm{CO}_{2}, \mathrm{~mL} / \mathrm{L}$ & 63.6 & 54.4 & 0.26 & $<0.01$ \\
\hline $\mathrm{CH}_{4}, \mathrm{~L} / \mathrm{kg} \mathrm{DM}$ intake & 29.9 & 21.1 & 1.44 & $<0.01$ \\
\hline $\mathrm{CH}_{4}, \mathrm{~L} / \mathrm{kg} \mathrm{OM}$ intake & 32.4 & 23.3 & 1.49 & $<0.01$ \\
\hline $\mathrm{CH}_{4}, \mathrm{~L} / \mathrm{kg} \mathrm{BW}$ & 1.02 & 0.82 & 0.05 & 0.02 \\
\hline \multicolumn{5}{|l|}{ Rumenfermentation } \\
\hline $\mathrm{pH}$ & 6.22 & 6.35 & 0.04 & 0.05 \\
\hline $\mathrm{NH}_{3}, \mathrm{mM}$ & 9.92 & 15.5 & 0.64 & 0.09 \\
\hline Total VFA, mM & 112 & 118 & 3.70 & 0.48 \\
\hline \multicolumn{5}{|l|}{ VFA, molarpercent } \\
\hline Acetate (A) & 69.9 & 68.1 & 0.51 & 0.07 \\
\hline Propionate (P) & 17.7 & 19.8 & 0.46 & 0.01 \\
\hline Isobutyrate & 0.95 & 0.79 & 0.05 & 0.08 \\
\hline Butyrate & 9.92 & 10.2 & 0.30 & 0.70 \\
\hline Isovalerate & 0.47 & 0.23 & 0.05 & $<0.01$ \\
\hline Valerate & 1.06 & 0.86 & 0.05 & 0.04 \\
\hline $\mathrm{A} / \mathrm{P}$ ratio & 3.96 & 3.46 & 0.11 & 0.01 \\
\hline
\end{tabular}

The protozoa population was increased $(\mathrm{P}<0.01)$ by the CAL diet (Table 11) as a result of the increased population of Entodiniomorpha; butHolotricha population decreased $(\mathrm{P}<0.01)$. M. elsdenii and $B$. proteoclasticuspopulations were higher $(\mathrm{P} \leq 0.02)$ in the $\mathrm{CAL}$ group than the CON group. Numbers of $R$. albus, Prevotella spp., and $B$. fibrisolvenstended to increase $(P=0.06 ; P=0.10 ; P=0.09$, respectively) with the CAL diet. The total methanogens and Methanobacteriales populations decreased $(P<0.01$ and $P=0.05$, respectively) due to $C A L$ supplementation. 
Table 11

The effect of CALon ruminal microbial populations in lambs (Experiment 3).

\begin{tabular}{|c|c|c|c|c|}
\hline Parameters & CON & CAL & SEM & $P$ value \\
\hline Total protozoa, $10^{5} / \mathrm{mL}$ & 6.47 & 8.43 & 0.45 & $<0.01$ \\
\hline Holotricha, $10^{5} / \mathrm{mL}$ & 0.05 & 0.02 & 0.01 & $<0.01$ \\
\hline Entodinomorpha, $10^{5} / \mathrm{mL}$ & 6.42 & 8.41 & 0.46 & $<0.01$ \\
\hline Total bacteria, $10^{9} / \mathrm{mL}$ & 4.89 & 4.77 & 0.09 & 0.55 \\
\hline Streptococcusbovis* & 1.01 & 0.83 & 0.26 & 0.75 \\
\hline Ruminococcusflavefaciens* & 1.00 & 0.94 & 0.24 & 0.91 \\
\hline Ruminococcusalbus* & 1.00 & 4.71 & 0.92 & 0.06 \\
\hline Megasphaeraelsdenii* & 1.00 & 7.68 & 1.44 & 0.03 \\
\hline Prevotella spp.* & 1.00 & 3.85 & 0.86 & 0.10 \\
\hline Lactobacillus spp.* & 1.00 & 0.10 & 0.47 & 0.38 \\
\hline Fibrobactersuccinogenes* & 1.00 & 5.60 & 1.89 & 0.24 \\
\hline Butyrivibrioproteoclasticus* & 1.00 & 15.9 & 3.03 & 0.02 \\
\hline Butyrivibriofibrisolvens* & 1.00 & 4.55 & 1.06 & 0.09 \\
\hline Total methanogens, $10^{8} / \mathrm{mL}$ & 5.08 & 3.61 & 0.28 & $<0.01$ \\
\hline Methanobacteriales, $10^{7} / \mathrm{mL}$ & 3.23 & 2.73 & 0.12 & 0.05 \\
\hline Methanomicrobiales, $10^{7} / \mathrm{mL}$ & 3.08 & 3.00 & 0.13 & 0.75 \\
\hline \multicolumn{5}{|c|}{ CON: Control diet; CAL: Coleus amboinicus Lour. herb diet; SEM: standard error of means } \\
\hline *Relative transcript abunda & & & & \\
\hline
\end{tabular}

In Experiment 3, the proportions of C16:0, C23:0, C24:1, LNA, PUFA, the sum of $n-6$, and the sum of n-3 FA in ruminal fluid were increased by the CAL diet $(P \leq 0.05$, Table 12). The CAL diet significantly decreased the proportions of C18:0 andC18:1 trans-10(P $\leq 0.05)$. Total SFA and PUFA/SFA tended to decrease while the total UFA tended to increase $(P \leq 0.10)$. The ruminal biohydrogenation percentage of $L A$ and $L N A$ decreased in the CAL diet $(P \leq 0.05)$. Stearic acid (C18:0), sum of SFA, thrombogenicity index ( $\mathrm{TI})$, and the atherogenicity index (AI) were decreased $(\mathrm{P} \leq 0.05)$ in LT muscle by CAL diet. The proportions of $\mathrm{C} 18: 3$ cis-9 cis-12 cis-15, sum of UFA, PUFA/SFA, total CLA, D $\Delta 9$, D $\Delta 9$ 18:1/18:0, $D \Delta 9$ RA/VA increased $(P \leq 0.05)$ in the muscle for the CAL diet. The proportions of total PUFA and total $n-3$ FA in LT muscle tended to increase $(P=0.07 ; P=0.07 ; P=0.08$, respectively) when the $C A L$ diet was used. 
Table 12

FA profile in rumen fluid and LT muscle of lambs fed CAL (Experiment 3).

\begin{tabular}{|c|c|c|c|c|c|c|c|c|}
\hline \multirow[t]{2}{*}{ Fatty acid, $\%$ of total FA } & \multicolumn{4}{|c|}{ Rumen fluid } & \multicolumn{4}{|c|}{ LT muscle } \\
\hline & CON & CAL & SEM & $P$ value & CON & CAL & SEM & $P$ value \\
\hline \multicolumn{9}{|l|}{ Saturated FA } \\
\hline C8:0 & 0.03 & 0.01 & 0.01 & 0.39 & 1.44 & 0.60 & 0.39 & 0.31 \\
\hline C10:0 & 0.08 & 0.49 & 0.14 & 0.16 & 1.85 & 1.49 & 0.41 & 0.68 \\
\hline $\mathrm{C} 12: 0$ & 0.64 & 0.98 & 0.13 & 0.19 & 1.62 & 1.23 & 0.26 & 0.48 \\
\hline C13:0 & 1.87 & 1.94 & 0.17 & 0.86 & 1.09 & 0.82 & 0.26 & 0.63 \\
\hline C14:0 & 1.11 & 1.29 & 0.14 & 0.56 & 1.77 & 1.62 & 0.26 & 0.79 \\
\hline C15:0 & 1.46 & 1.44 & 0.13 & 0.92 & 1.13 & 1.11 & 0.22 & 0.96 \\
\hline C16:0 & 16.5 & 18.7 & 0.49 & 0.01 & 14.1 & 12.5 & 0.50 & 0.11 \\
\hline $\mathrm{C} 17: 0$ & 0.73 & 0.62 & 0.07 & 0.48 & 0.87 & 1.07 & 0.13 & 0.48 \\
\hline C18:0 & 47.3 & 40.9 & 1.59 & 0.03 & 15.4 & 12.1 & 0.73 & 0.01 \\
\hline C20:0 & 0.06 & 0.06 & 0.02 & 0.86 & 0.21 & 0.20 & 0.04 & 0.88 \\
\hline $\mathrm{C} 21: 0$ & 0.05 & 0.11 & 0.02 & 0.17 & 0.26 & 0.38 & 0.07 & 0.41 \\
\hline $\mathrm{C} 22: 0$ & 0.11 & 0.08 & 0.02 & 0.37 & 0.52 & 0.65 & 0.08 & 0.44 \\
\hline C23:0 & 0.09 & 0.21 & 0.03 & 0.02 & 0.34 & 0.71 & 0.11 & 0.10 \\
\hline $\mathrm{C} 24: 0$ & 0.56 & 0.55 & 0.03 & 0.87 & 0.18 & 0.50 & 0.09 & 0.09 \\
\hline \multicolumn{9}{|l|}{ Monounsaturated FA } \\
\hline C14:1 & 0.24 & 0.28 & 0.06 & 0.76 & 0.69 & 0.96 & 0.17 & 0.45 \\
\hline C15:1 & 1.11 & 0.87 & 0.12 & 0.32 & 1.57 & 1.49 & 0.20 & 0.84 \\
\hline C16:1 & 0.31 & 0.32 & 0.05 & 0.96 & 1.03 & 0.99 & 0.14 & 0.89 \\
\hline $\mathrm{C} 17: 1$ & 0.17 & 0.17 & 0.05 & 0.99 & 1.24 & 1.71 & 0.18 & 0.20 \\
\hline C18:1 trans-10 & 0.62 & 0.48 & 0.04 & 0.05 & 0.30 & 0.21 & 0.03 & 0.12 \\
\hline C18:1 trans-11 (VA) & 5.25 & 4.41 & 0.30 & 0.19 & 1.07 & 0.75 & 0.10 & 0.11 \\
\hline C18:1 cis-9 & 6.98 & 7.53 & 0.37 & 0.49 & 22.1 & 22.4 & 1.11 & 0.92 \\
\hline C18:1 cis-11 & 1.65 & 1.68 & 0.06 & 0.83 & 2.30 & 2.17 & 0.12 & 0.62 \\
\hline C18:1 cis-12 & 0.57 & 0.68 & 0.06 & 0.46 & 0.77 & 0.62 & 0.08 & 0.37 \\
\hline C18:1 cis-13 & 0.12 & 0.19 & 0.03 & 0.26 & 0.23 & 0.21 & 0.05 & 0.86 \\
\hline C18:1 cis-14 & 1.00 & 0.81 & 0.10 & 0.36 & 0.63 & 0.50 & 0.11 & 0.57 \\
\hline C20:1 trans- & 0.84 & 0.90 & 0.03 & 0.36 & 0.52 & 0.64 & 0.11 & 0.64 \\
\hline $\mathrm{C} 22: 1 n-9$ & 0.16 & 0.09 & 0.03 & 0.22 & 0.38 & 0.60 & 0.09 & 0.23 \\
\hline
\end{tabular}




\begin{tabular}{|c|c|c|c|c|c|c|c|c|}
\hline \multirow[t]{2}{*}{ Fatty acid, $\%$ of total FA } & \multicolumn{4}{|c|}{ Rumen fluid } & \multicolumn{4}{|c|}{ LT muscle } \\
\hline & CON & CAL & SEM & $P$ value & CON & CAL & SEM & $P$ value \\
\hline $\mathrm{C} 24: 1$ & 0.14 & 0.71 & 0.11 & $<0.01$ & 1.44 & 1.92 & 0.14 & 0.10 \\
\hline \multicolumn{9}{|l|}{ Polyunsaturated FA } \\
\hline C18:2 cis-12 trans-10 (CLA-t10) & 0.17 & 0.66 & 0.15 & 0.18 & 0.51 & 0.56 & 0.10 & 0.82 \\
\hline C18:2 cis-9 trans-11 (RA) & 0.49 & 0.37 & 0.05 & 0.21 & 0.44 & 0.69 & 0.11 & 0.27 \\
\hline C18:2 cis-9 cis-12 (LA) & 6.42 & 8.07 & 0.40 & 0.02 & 15.1 & 17.6 & 0.93 & 0.19 \\
\hline C18:3 cis-6 cis-9 cis-12 & 0.15 & 0.27 & 0.04 & 0.11 & 0.49 & 0.57 & 0.09 & 0.67 \\
\hline C18:3 cis-9 cis-12 cis-15 (LNA) & 1.47 & 2.28 & 0.16 & $<0.01$ & 1.05 & 1.73 & 0.19 & 0.05 \\
\hline $\mathrm{C} 20: 2$ & 0.43 & 0.37 & 0.06 & 0.63 & 0.35 & 0.44 & 0.10 & 0.68 \\
\hline C20:3 n-6 & 0.63 & 0.65 & 0.07 & 0.89 & 4.04 & 5.11 & 0.38 & 0.17 \\
\hline C20:4 n-6 & nd. & nd. & nd. & nd. & 0.51 & 0.42 & 0.05 & 0.44 \\
\hline C20:5 n-3 & nd. & nd. & nd. & nd. & 0.74 & 0.64 & 0.14 & 0.73 \\
\hline $\mathrm{C} 22: 2$ & 0.08 & 0.16 & 0.04 & 0.28 & 0.62 & 0.49 & 0.15 & 0.72 \\
\hline $\mathrm{C} 22: 5 \mathrm{n}-3$ & nd. & nd. & nd. & nd. & 0.64 & 0.90 & 0.09 & 0.17 \\
\hline C22:6 n-3 & nd. & nd. & nd. & nd. & 0.45 & 0.79 & 0.15 & 0.27 \\
\hline$\sum$ SFA & 70.5 & 67.3 & 0.96 & 0.10 & 40.8 & 34.9 & 1.24 & 0.01 \\
\hline$\sum$ UFA & 29.5 & 32.7 & 0.96 & 0.10 & 59.2 & 65.1 & 1.24 & 0.01 \\
\hline$\sum$ MUFA & 18.7 & 20.1 & 0.60 & 0.66 & 34.3 & 35.1 & 0.95 & 0.70 \\
\hline$\sum$ PUFA & 10.8 & 12.5 & 0.51 & $<0.01$ & 24.9 & 30.0 & 1.01 & 0.07 \\
\hline$\sum n-6$ & 8.90 & 9.72 & 0.42 & 0.02 & 21.6 & 25.2 & 1.23 & 0.17 \\
\hline$\sum n-3$ & 1.47 & 2.28 & 0.16 & $<0.01$ & 2.88 & 4.06 & 0.31 & 0.07 \\
\hline$n-6 / n-3$ & 6.05 & 4.37 & 0.39 & 0.02 & 7.86 & 6.74 & 0.73 & 0.47 \\
\hline PUFA/SFA & 0.15 & 0.19 & 0.01 & 0.07 & 0.62 & 0.86 & 0.05 & 0.01 \\
\hline LNA/LA & 0.21 & 0.30 & 0.02 & 0.02 & 0.07 & 0.10 & 0.01 & 0.31 \\
\hline$\sum \mathrm{C} 18: 1$ & 15.7 & 16.8 & 0.64 & 0.45 & 27.4 & 26.8 & 1.22 & 0.81 \\
\hline$\sum \mathrm{C} 18: 1$ trans- & 5.48 & 5.08 & 0.28 & 0.52 & 1.37 & 0.96 & 0.11 & 0.06 \\
\hline$\sum \mathrm{C} 18: 1 \mathrm{cis}^{-}$ & 10.2 & 11.7 & 0.58 & 0.23 & 26.1 & 25.8 & 1.19 & 0.94 \\
\hline$\sum \mathrm{CLA}$ & 0.64 & 0.99 & 0.19 & 0.36 & 0.95 & 1.61 & 0.18 & 0.04 \\
\hline$\sum$ MCFA & 23.3 & 26.3 & 0.94 & 0.12 & 26.3 & 22.8 & 1.25 & 0.17 \\
\hline$\sum$ LCFA & 76.7 & 73.7 & 0.94 & 0.12 & 73.7 & 77.2 & 1.25 & 0.17 \\
\hline $\mathrm{BH}$ intermediates & 7.81 & 7.76 & 0.46 & 0.95 & nd. & nd. & nd. & nd. \\
\hline LA BH (\%) & 74.2 & 67.6 & 1.58 & 0.03 & nd. & nd. & nd. & nd. \\
\hline LNA BH (\%) & 94.4 & 91.5 & 0.61 & $<0.01$ & nd. & nd. & nd. & nd. \\
\hline RA/VA & 0.08 & 0.11 & 0.02 & 0.50 & nd. & nd. & nd. & nd. \\
\hline Desaturation index (DI) $\Delta 9$ & nd. & nd. & nd. & nd. & 0.41 & 0.47 & 0.01 & 0.01 \\
\hline $\mathrm{D} \Delta 9 . \mathrm{C} 14: 1 / \mathrm{C} 14: 0$ & nd. & nd. & nd. & nd. & 0.29 & 0.37 & 0.06 & 0.50 \\
\hline
\end{tabular}




\begin{tabular}{|c|c|c|c|c|c|c|c|c|}
\hline \multirow[t]{2}{*}{ Fatty acid, $\%$ of total FA } & \multicolumn{4}{|c|}{ Rumen fluid } & \multicolumn{4}{|c|}{ LT muscle } \\
\hline & CON & CAL & SEM & $P$ value & CON & CAL & SEM & $P$ value \\
\hline $\mathrm{D} \Delta 9.16: 1 / 16: 0$ & nd. & nd. & nd. & nd. & 0.07 & 0.07 & 0.01 & 0.85 \\
\hline $\mathrm{D} \Delta 9.18: 1 / 18: 0$ & nd. & nd. & nd. & nd. & 0.59 & 0.65 & 0.01 & 0.01 \\
\hline $\mathrm{D} \Delta 9 . \mathrm{RA} / \mathrm{VA}$ & nd. & nd. & nd. & nd. & 0.27 & 0.48 & 0.06 & 0.04 \\
\hline $\mathrm{D} \Delta 9$. MUFA/SFA & nd. & nd. & nd. & nd. & 0.46 & 0.50 & 0.01 & 0.08 \\
\hline$D \Delta 5 . n-6.20: 4 n-6 / 20: 3 n-6$ & nd. & nd. & nd. & nd. & 0.12 & 0.08 & 0.01 & 0.11 \\
\hline$D \Delta 5$. D6. n-6. 20:4n-6/18:3n-6 & nd. & nd. & nd. & nd. & 0.53 & 0.43 & 0.06 & 0.43 \\
\hline$D \Delta 4 . n-3.22: 6 n-3 / 22: 5 n-3$ & nd. & nd. & nd. & nd. & 0.33 & 0.41 & 0.06 & 0.53 \\
\hline Elongase index & nd. & nd. & nd. & nd. & 0.71 & 0.72 & 0.01 & 0.92 \\
\hline Thrombogenic index & nd. & nd. & nd. & nd. & 0.85 & 0.62 & 0.05 & $<0.01$ \\
\hline Atherogenicity index & nd. & nd. & nd. & nd. & 0.63 & 0.48 & 0.03 & 0.03 \\
\hline
\end{tabular}

The CAL diet significantly decreased the mRNA expressions of FADS1, FASN, LPL, and SCD genes, but not the expression of ELOVL5 (Fig. 1). The CAL diet also significantly affected some meat characteristics. Lightness color and water-holding capacity of meat were reduced, whereas meat juiciness was increased ( $P \leq 0.01$, Table 13) by CAL diet. Redness and flavor values tended to increase $(P=0.09 ; P=0.06$, respectively), whereas the ash content tended to decrease due to CAL supplementation $(P=0.09)$.

Table 13

The LT muscle qualityand characteristicsof lamb fed CAL(Experiment 3).

\begin{tabular}{|c|c|c|c|c|c|}
\hline Trait & Unit & Treatments & & SEM & $P$-value \\
\hline & & $\operatorname{CON}(n=4)$ & $\operatorname{CAL}(n=4)$ & & \\
\hline Muscle pH 24 h post mortem & pHunits & 5.58 & 5.69 & 0.05 & 0.39 \\
\hline$L^{*}$, lightness & units & 41.4 & 37.0 & 0.88 & 0.01 \\
\hline$a^{\star}$, redness & units & 12.1 & 13.2 & 0.31 & 0.09 \\
\hline$b^{\star}$, yellowness & units & 4.81 & 4.65 & 0.36 & 0.84 \\
\hline Water-holding capacity, \% & & 38.6 & 29.5 & 1.69 & $<0.01$ \\
\hline Watercontent, \% & & 72.9 & 73.3 & 0.24 & 0.40 \\
\hline Intramuscularfatcontent, \% & & 2.58 & 2.36 & 0.07 & 0.13 \\
\hline Total protein content, \% & & 23.3 & 23.0 & 0.25 & 0.58 \\
\hline Ash content, \% & & 1.16 & 1.13 & 0.01 & 0.09 \\
\hline \multicolumn{6}{|l|}{ Sensory evaluations } \\
\hline Aroma & $1-5$ & 4.28 & 4.29 & 0.05 & 0.85 \\
\hline Juiciness & $1-5$ & 4.19 & 4.57 & 0.08 & 0.01 \\
\hline Tenderness & $1-5$ & 4.15 & 4.36 & 0.07 & 0.13 \\
\hline Flavor & $1-5$ & 4.07 & 4.31 & 0.07 & 0.06 \\
\hline \multicolumn{6}{|l|}{ Subjectivevisualevaluations } \\
\hline Color & $1-8$ & 2.38 & 2.56 & 0.10 & 0.38 \\
\hline Marbling & $1-4$ & 1.59 & 1.53 & 0.06 & 0.63 \\
\hline
\end{tabular}




\section{Discussion}

\section{Nutrients and phytochemical composition of Coleus amboinicus Lour.}

Several studies confirmed that CAL is rich in nutrients, ash, and BACs $[10,12,13,39]$. It has been shown that $C$. amboinicus Lour., known also as Plectranthus amboinicus,as well as other species of the genus Plectranthus (Lamiaceae) such as P. madagascariensis and P. ecklonii have distinct BAC contents [10,39]. In comparison to our previous study [13], the CAL examined in this experiment was characterized by higher concentrations of protein(214 vs. $196 \mathrm{~g} / \mathrm{kg} \mathrm{DM})$, aNDF (405 vs. $363 \mathrm{~g} / \mathrm{kg} \mathrm{DM}$ ), $a$-linolenic acid (45.1 vs. $35.83 \mathrm{~g} / 100 \mathrm{~g} \mathrm{FA),} \mathrm{and} \mathrm{total} \mathrm{PUFA} \mathrm{(59.2}$ vs. $56.15 \mathrm{~g} / 100 \mathrm{~g} \mathrm{FA}$ ). Regarding BACs, similar concentrations of phenolic acids were detected as in Yanza et al. [13], but the levels of flavonoids and diterpenes were significantly higher (four and nine times, respectively) in this study. The most abundant component in this study was acetyldihydroxyroyleanone (13.4 mg/g DM), but rosmarinic acid dominated in CAL in Yanza et al. [13] study. The content of particular BAC in plants may be attributed to a range of factors, such as geographical area, soil condition, agronomic management, and stage of plant vegetation[40]. The differences between these results and those of Yanza et al. [13] may be attributable to differences in the plant material used, such as in harvesting times (2-3 months and 4-6 months, respectively) and management of plantation (e.g., watering and fertilizer application). The CAL used in this study had higher BAC content than that in Yanza et al. [13], study and thus had more pronounced action in the rumen.

\section{In vitro experiment (10-day RUSITEC fermentation, Experiment 1)}

Identification of the concentration of particular BAC in the CAL undoubtedly helped to interpret our results. The gradual replacement of a proportion of the main diet (from 10-20\%) by CAL decreased methane production and gradually diminished population of ruminal methanogens (both total methanogens and methanogen species observed). The greatest reduction in total methanogen population (by $24 \%$ ) as well as the most effective mitigation of $\mathrm{CH}_{4}$ production (by 49\%) was observed for the $20 \% \mathrm{CAL}$ diet. As in our previous study [13], no negative changes in rumen parameters were noted. Our findings are also supported by other authors[41, 42], who demonstrated $\mathrm{CH}_{4}$ reduction in response to BAC of plant origin, with no negative consequences such as declined feed degradability, changes in ammonia, total VFA concentration, or microbial population (total protozoa and bacteria population). We have also noted the inhibition of methanogens via a direct toxic antibacterial effect of BAC, but without adverse effects on ruminal fermentation or DM degradability. Despite the toxic action of BAC on methanogens, no effect on protozoa and ruminal bacteria was observed. Only the lowest level of CAL (10\%) increased the population of the bacteria Prevotellaspp., B. proteoclasticus, and B. fibrisolvens. A distinct effect of the lowest CAL supplementation was also observed in our previous study on Saponaria officinalis[43]. We hypothesized that the basic nutrient components of a plant can either interact with BAC or become physically less available for microbiota, resulting in a decreased antibacterial activity.Moreover, the reduction in the methanogen population resulting from the antimethanogenic effect of CAL lowered the acetate:propionate ratio, probably by shifting the free-hydrogen pathways to propionate production. Our findings corroborated with an experiment on Rosmarinus officinaliscontaining diterpenes (such as carnosol, carnosic acid, rosmanol, epirosmanol, isorosmanol, and methyl carnosate) added to a ruminant diet [44]. This supplement affected several groups of rumen microbes involved in protein and fiber degradation as well as $\mathrm{CH}_{4}$ and ammonia production. Coleus amboinicus (Lour.) is a rich source of UFA with the predominance of $a$-linolenic acid (LNA). The higher fat concentration in CAL than in grass silage (43 vs $21 \mathrm{~g} / \mathrm{kg} \mathrm{DM}$, respectively) may increase the ruminal FA content, and consequently that of LNA. The effect of CAL in the diet on FA profile in the rumen differed from that on bacteria population. For the majority of FA, the significant effect was observed for all CAL (10\%, $15 \%$, and $20 \%$ ) diets.

Dietary CAL modulated the ruminal FA composition by lowering SFA and elevating MUFA and PUFA proportions. The alterations in MUFA and PUFA profiles may suggest the changes in $\mathrm{BH}$ process in the rumen. We showed in our short-term study that the polyphenol compounds of $\mathrm{CAL}$ origin (flavonoid, phenolic acids, and diterpenes) can alter the action of the ruminal microbiota involved in $\mathrm{BH}$ [13]. We also noted higher content of total polyphenols and diterpenes of CAL origin in this long-term study compared with our previous short-term study [13]. The CAL diet decreased C18:1 trans concentration due to the $\mathrm{BH}$ process of $\mathrm{LA}$. High quantities of polyphenols and diterpenes reduced the final $\mathrm{BH}$ step of the C18:1 cis-9 and caused a linear decrease in the concentration of stearic acid (C18:0). This was also observed by Vasta et al. [5], who described a negative effect of different polyphenols on C18:0 accumulation in the rumen digesta. The results of the current study thus demonstrate the protective action of CAL on BH of MUFA and PUFA.

\section{In vivo experiments: Experiment 2 with cannulated lambs and Experiment 3 with growing lambs.}

The many ruminal fermentation characteristicsin the growing lambs receiving $200 \mathrm{~g} /$ day of CAL corroborated with the results of the in vitro study. Methane emission (L/d and L/DM intake) was mitigated by $20 \%$ and $29 \%$, respectively, and did not interfere with DM, OM, or NDF digestibility. Decreases in $\mathrm{CH}_{4}$ production are usually associated with adverse effects on fiber digestibility [45]. We suggest that, in this case, $\mathrm{CH}_{4}$ mitigation was attributed directly to the reduction in total methanogen and Methanobacterialespopulation (in both growing and cannulated lambs), as well asin Methanomicrobiales populations (in the cannulated lambs) rather than reduction of carbohydrate digestibility [41]. These

Page 22/29 
results are supported by our previous short-term in vitro studies investigating BAC from two sources (Sanguisorba officinalis and CAL), where there were no negative effects on in vitro parameters, including DM degradability [13].

The utilization of forages in ruminants requires the coordinatedactivity of bacteria (such as $F$. succinogenes, $R$. albus, $R$. flavefaciens, and $B$. fibrisolvens), protozoa, and fungi for proper digestion[5, 46, 47]. Digestibility is also affected by the number and composition of rumen microorganisms. Supplementing the diet with $200 \mathrm{~g} /$ day of CAL had a positive effect on the total protozoa population in growing lambs (Experiment 3). The effect was more pronounced for a few particular bacterial species (namely R. albus, M. elsdenii, B. proteoclasticus, and $B$. fibrisolvens) than for the total bacteria. In comparison with tannins, BAC of CAL origin exerted either less negative impact on the rumen environment, or else their concentration was more beneficial on the ruminal microorganisms. This is supported by De Nardi et al. [48], who reported an increase in the number of several ruminal bacteria in heifers due to supplementation of flavonoids and essential oils.

Neither digestibility nor total VFA concentration was affected in the present study, although alterations in individual VFAs, such as propionic acid, were noted. The high proportion of propionate was not linked with the abundance of $S$. bovis, the amylolytic bacteria responsible for production of this VFA. The possibility cannot be however excluded that other amylolytic bacteria, not investigated in this study, were not affected. Additionally, higher concentration of propionic acid and lower acetic to propionic ratio can reflect in decreased hydrogen accessible to methanogens[49]. Considering the direct reduction in methanogen count caused by BAC of CAL origin, such a pathway has rather limited importance for mitigation of methanogenesis in this study.

Another aspect of this experiment that is worthy of attention is the changes observed in nitrogen metabolizing bacteria population (Prevotella spp., B. proteoclasticus, and B. fibrisolvens). CAL is a feed rich in total protein (214 g/ $\mathrm{kg} \mathrm{DM})$, and is thus the perfect substrate for $\mathrm{N}$ metabolism in the rumen. We observed an increase in ruminal ammonia in response to CAL supplementation. It is known that tannins form complexes with proteins, reducing the ammonia level in the rumen fluid. In the present study, protein degradation was not likely limited by CAL. Besides, the higher protein content may influence the ammonia level.

The in vivo experiments had higher ruminal $\mathrm{pH}$ values. Our observation corroborated the result ofBalcells et al. [50], who observedhigher $\mathrm{pH}$ after supplementing dairy cow diet with flavonoids. The extent of rumen fermentation reflected by the total VFA suggests that CAL supplementation did not affect this variable (Experiment 2 and Exp.3). Microbial activity is affected by the properties of the substrate, and higher starch levels in the diet usually reduce the $\mathrm{pH}$ of the rumen fluid $[51,52]$. The diets in the present study were rich in concentrate (400 $\mathrm{g} /$ day) and we expected a reduction in $\mathrm{pH}$. According to Balcells et al. [50], flavonoid supplementation may improve rumen fermentation and reduce the incidence of rumen acidosis. Such activity of some flavonoids may be partially explained by the increased number of lactateconsuming microorganisms (e.g., M. elsdenii). Our studies also confirmed this activity of CAL flavonoids by demonstrating increased pH values in the lamb rumen. It should be realized that the CAL contained three types of BAC with distinct activities: flavonoids, diterpenes and phenolic acidsbut the mechanism described above is typical for flavonoids. Another mechanism that may stabilize the $\mathrm{pH}$ is the fluctuations of protozoa community. According to Hartinger et al. [53], protozoa incorporate starch granules that are not metabolized to organic acids quickly. Thus, protozoa protect the rumen from large drops in $\mathrm{pH}$, and support stable fermentation conditions. The effect of CAL on rumen protozoa observed in the present study was ambiguous. The Entodiniomorphapopulation significantly increased (Table 11), whereas that of Holotricha diminished consistently (Tables 9, 11). Similar trends were described in our short-term study [13], so we can assume that this mode of CAL action is stable for a longer period.

The FA proportion of the rumen fluid was another parameter affected by supplementation with CAL. We noted a positive alteration in the ruminal PUFA proportion in the growing lambs, which can mainly be attributed to the increase in C18:3 cis-9 cis-12 cis-15 FAs in the rumen fluid and meat (Table 12). The CAL polyphenols likely increased the bypass of UFA. Although the majority of bacterial communities involved in BH increased in number, BH of C18 UFA into stearic acid (C18:0) was lower due to CAL supplementation. A similar result was reported by Vasta et al. [5], who, regardless of the type of polyphenol supplementation, observed a reduction in ruminal C18:0 and an increase in C18:1 trans-11 (VA) and C18:2 cis-9 trans-11 (CLA) isomers. Vasta et al.[5] also pointed out a range of actions of polyphenols on bacteria involved in the $\mathrm{BH}$ process. The stability of the main $\mathrm{BH}$ isomers and the distinct responses of two bacteria species involved in $\mathrm{BH}$ process (B. fibrisolvens and B.proteoclasticus) observed in our study can also demonstrate some other properties of polyphenols. The reduction of BH by CAL despite greater populations of $\mathrm{BH}$ bacteria may suggest that CAL may reduce the content of free FA, substrates to $\mathrm{BH}$ process due to decreased lipolysis [4]. Besides, a reduction in the numbers of several bacteria species involved in $\mathrm{BH}$, such as Neisseria weaverii, $R$. amylophilus, and other unclassified bacteria related to the Lachnospiraceaeand Pasteurellaceaefamilies was observed [54]. In this study, the potential restriction on $\mathrm{BH}$ may be supported by the fact that the rumen and meat displayed similar alterations in the FA profile, which likely suggests that the rumen was the locus of the main changes.

Transcript analysis included a panel of five genes of known function in FA metabolism in ruminant muscles [55]. Three of the genes (FASN, $S C D$, and ELOVL5) control the de novo synthesis and elongation of FA, whereas the $L P L$ and FADS1 genesare involved in FA transport. However, that considering the complexity of the entire gene expression process and the great variation seen in transcript lifespans, any conclusions must

Page $23 / 29$ 
be drawn with caution. Meat from lambs fed the CAL diet was characterized by a significant reduction in the mRNA content of four genes (FASN, SCD, LPL, and FADS1), whereas no changes were observed for the ELOVL5 transcript. Alterations in the transcript expression of genes regulating lipid metabolism was not reflected in the profile of FA controlled by those genes. For example, the reduced mRNA level of the $S C D$ gene was not accompanied by a lower level of C18:1 cis-9. According to Garnsworthy et al. [56], the level of C18:1 cis-9 in the fat of ruminant products is highly dependent upon the $S C D$ gene controlling de novo FA synthesis. Besides, the lack of difference in $C 18: 1$ cis-9 concentration in response to CAL supplementation may suggest that the synthesis of endogenous FA was unaffected. On the other hand, the reduced transcript levels of the $L P L$ gene may be associated with the decreased biosynthesis of MUFA. The lack of alteration in the mRNA content of the ELOVL5 gene regulating FA elongation and the increased n-3 concentration (mainly LNA) in meat may reflect n-3 metabolism in the rumen, rather than that in muscles. Considering the reduced transcript content of another two genes-FADS1 and FASN-this may be linked to the inhibition of the initial stages of the $\mathrm{BH}$ process.Pewan et al. [57]suggested that the FASN protein complex controls de novo biosynthesis of long-chain FA and affects FA deposition in meat, adipose tissue, and milk. The published evidence on the correlations between n-3 PUFA profile, the activity of lipogenic genes (such as FASN), and meat quality, however, is very limited [57].Nevertheless, the n-3 PUFA profile of the meat of lambs fed CAL was improved, which suggests that changes in the FA profile had already occurred in the rumen, leading to more PUFA being available to the tissue. Higher n-3 PUFA levels in meat are beneficial to human health and support cardiovascular, retinal, and brain functions [58, 59]. Positive changes in the FA profile of meat from the experimental lambs increased its quality. However, higher content of PUFAs could decrease the meat shelf life due to a rapid oxidization of FAs ensuing from two or more double bonds in their structure [60].

The oxidative process can shorten the shelf life of fresh meat and negatively affect its consumption by the formation of off-flavors and discoloration [61]. The sensor attributes, likes juiciness and taste, are generally associated with the consumers' preferences[62]. In this study, we observed improved meat characteristics such as juiciness or taste. The better meat sensory quality combined with improved indices of thrombogenicity ( $\mathrm{TI}$ ) and atherogenicity (Al) indexes may help to encourage consumers to select quality meat in the future. Tannin-containing diets sometimes reduce [63] or unchanged [64] tenderness and juiciness of meat depending upon the doses. In this study, juiciness and flavor of lamb meat increased, which would be advantageous from consumer perspectives. It has been suggested that phenolic compounds may increase the activity calpains and accelerating the degradation of myofibrillar proteins during the postmortem conditioning of carcass, leading to increased juiciness and tenderness of meat $[65,66]$. A study with Andrographis paniculata, an annual herb rich in polyphenols,reported that this herb increased the juiciness and tenderness of the LT muscle of goats [66]. Previous study reported that dietary polyphenols from Mimosa condensed tannins had no influence on meat lightness and colors of lambs, however the meat metmyoglobin was reduced [67]. Polyphenol inclusion in ruminants' diet might cause different effects on the meat color. Many studies suggested that dietary polyphenols might cause a lighter color of meat $[68,69]$. Priolo et al. [70] evaluated the effect of tannin in lambs and stated that the longissimus muscle was lighter (lower

$\left.L^{*}\right)$ in tannin-fed group. We assume that the lower lightness and greater redness of color in the present study were influenced by the CAL mineral content, which was not determined in this study. Damanik et al. [12] reported that the CAL contains high concentrationof iron (Fe). Garg et al. [71] stated that the inclusion of tannin in the animal diets do not hamper the utilization of iron for the hemoglobin synthesis. Thus, lambs fed CAL diet might influence its carcass color and lightness due to the high level of Fe affecting the hemoglobin synthesis in the meat. Moreover, polyphenols with high antioxidant activities may reduce the oxidation of myoglobin leading to increased the redness of meat [61]. Increased redness of meat has also been reported due to feeding of polyphenol-rich plants [66, 72].

\section{Conclusions}

Polyphenols of $\mathrm{CAL}$ origin reduce $\mathrm{CH}_{4}$ production, which is associated with diminished Archaea communities. Polyphenols of CAL modulate the final products of ruminal fermentation and lowers the A/P ratio, with no alteration in ruminal digestibility. CAL also affect ruminal bacteria involved in fermentation and BH by elevating LNA concentration, and ultimately increase deposition of n-3 PUFA. Dietary CAL also improves the meat quality. Coleus amboinicus Lour. herb can be used in ruminant nutrition to reduce greenhouse gas emissions and improve meat quality without any negative effects on ruminal fermentation and growth performance.

\section{Abbreviations}

ADG: Average daily gain; Al: Atherogenicity; aNDF: Ash free NDF; A/P ratio: Acetate/Propionate ratio; BAC: Biologically active compounds; BH: Biohydrogenation; BW: Body weight; CAL: Coleus amboinicus Lour.; $\mathrm{CH}_{4}$ : Methane emission; $\mathrm{CO}_{2}$ : Carbon dioxide emission; CLA: Conjugated linoleic acid;CP: Crude protein; D $\Delta$ : Desaturation $\Delta$ at - $n$; DAPI: 4,6-diamidino-2-phenylindole; DI: Desaturation index; DM: Dry matter; DMD: Dry matter digestibility; DMI: Dry matter intake; DNA: Deoxyribonucleic acids; EE: Ether extract; El: Elongase index;ELOVL5: Fatty acid elongase 5; FA: Fatty acids;FADS1: Fatty acid desaturase 1; FASN: Fatty acid synthase;FISH: Fluorescence in situ hybridization; IVDMD: in vitro dry matter digestibility; LA: $a$-Linoleic acids; LCFA: Long chain fatty acids; LT muscle: Longissimus thoracismuscle;LNA: $a$-Linolenic acids; LPL: Lipoprotein lipase; MCFA: Medium chain fatty acids; mRNA: messenger-RNA;MUFA: Monounsaturated fatty acids; NDFD: Neutral detergent fibre digestibility; $\mathrm{NH}_{3}$ : Ammonia; OM: Organic matter;PBS: Phosphate-buffered saline;PUFA: Polyunsaturated fatty acids;qPCR: Quantitative PCR; RA: rumenic acid; RTA: Relative transcript abundance ( $\Delta \Delta \mathrm{CT})$; RUSITEC: Rumen simulation technique;SCD: Stearoyl-CoAdesaturase; SFA: 
Saturated fatty acids;SPE: Solid Phase Extraction;TI: Thrombogenicity; UFA: Unsaturated fatty acids; VA: Vaccenic acid; VFA: Volatile fatty acids;

\section{Declarations}

\section{Acknowledgements}

The authors are grateful to the Polish National Agency for Academic Exchange (NAWA) for awarded YRY the Ignacy Lukasiewicz scholarship (NAWA 015/IL/1617). The authors are grateful to Magda Bryszak, Haihao Huang, Min Gao and Sylwia Inglot for their technical assistance.

\section{Authors' contributions}

YRY designed the study protocol, provided laboratory analysis, helped with statistical analyses, interpreted the data and wrote first version of the manuscript. MSz interpreted the data and improved the manuscript. DL interpreted the data, reviewed and improved the manuscript. SS provided laboratory analysis of plants' phenolic acid, flavonoid, and diterpenoid contents. PK performed the laboratory analysis. AKP interpreted the data, revised the content substantially and reviewed the manuscript. ZV provided laboratory analysis of rumen fluid.DLi provided laboratory analysis of meat. MV interpreted the data and collected references for discussion. AC designed the study protocol, interpreted the data, wrote the manuscript, and finally reviewed the manuscript. All authors read and approved the final manuscript.

\section{Funding}

This study was funded by the National Science Centre funding program Grant 2018/31/N/NZ9/01589.

\section{Availability of data and materials}

The experimental datasets of the present study can be obtained from the corresponding author on reasonable request.

\section{Ethics approval of experiments to animal}

All experimental procedures were performed in accordance with the guidelines of the National Ethical Commission for Animal Research (Ministry of Science and Higher Education, Poland). The study was approved by the Local Ethical Commission of Poznan University of Life Sciences(license permit no. 35/2019).

\section{Competing interests}

The authors declare that they have no competing interests.

\section{References}

1. Vargas JE, Andres S, Lopez-Ferreras L, Snelling TJ, Yanez-Ruíz DR, García-Estrada C. LopezS. Dietary supplemental plant oils reduce methanogenesis from anaerobic microbial fermentation in the rumen. SciRep. 2020;10:1-9. https://doi.org/10.1038/s41598-020-58401-z.

2. Springmann M, Clark M, Mason-D'Croz D, Wiebe K, Bodirsky BL, Lassaletta L, de Vries W, VermeulenSJ HerreroM, Carlson KM, Jonell M, TroelIM, DeClerck F, Gordon LJ, Zurayk R, Scarborough P, Rayner M, LokenB FanzoJ, Godfray HCJ, Tilman D, Rockstrom J, Willett W. Options for keeping the food system within environmental limits. Nature. 2018;562:519-25. https://doi.org/10.1038/s41586-018-0594-0.

3. LanW YC. Ruminal methane production: Associated microorganisms and the potential of applying hydrogen-utilizing bacteria for mitigation. SciTotal Environ. 2019;654:1270-83. https://doi.org/10.1016/j.scitotenv.2018.11.180.

4. Buccioni A, Decandia M, Minieri S, Molle G, Cabiddu A. Lipid metabolism in the rumen: New insights on lipolysis and biohydrogenation with an emphasis on the role of endogenous plant factors. Anim Feed SciTechnol. 2012;174:1-25. https://doi.org/10.1016/j.anifeedsci.2012.02.009.

5. VastaV, Daghio M, Cappucci A, BuccioniA, Serra A, VitiC. MeleM. Invited review: Plant polyphenols and rumen microbiota responsible for fatty acid biohydrogenation, fiber digestion, and methane emission: Experimental evidence and methodological approaches. JDairy Sci. 2019;102:3781-804. https://doi.org/10.3168/jds.2018-14985.

6. Guil-Guerrero JL, Ramos L, Moreno C, Zuniga-ParedesJC, Carlosama-Yepez M, Ruales P. Plant foods by-products as sources of healthpromoting agents for animal production: A review focusing on the tropics. AgronJ. 2016;108:1759-74. https://doi.org/10.2134/agronj2015.0555.

7. Tullo E, Finzi A, Guarino M. Review. Environmental impact of livestock farming and Precision Livestock Farming as a mitigation strategy. Sci Total Environ. 2019;650:2751-60. https://doi.org/10.1016/j.scitotenv.2018.10.018. 
8. Buccioni A, Pauselli M, Viti C, Minieri S, Pallara G, Roscini V, Rapaccini S, MarinucciMT, Lupi P, Conte G, Mele M. Milk fatty acid composition, rumen microbial population, and animal performances in response to diets rich in linoleic acid supplemented with chestnut or quebracho tannins in dairy ewes. JDairy Sci. 2015;98:1145-56. https://doi.org/10.3168/jds.2014-8651.

9. Bryszak M, Szumacher-Strabel M, El-Sherbiny M, Stochmal A, Oleszek W, Roj E, Patra AK, Cieslak A. Effects of berry seed residues on ruminal fermentation, methane concentration, milk production, and fatty acid proportions in the rumen and milk of dairy cows. JDairy Sci. 2019;102:1257-73. https://doi.org/10.3168/jds.2018-15322.

10. Arumugam G, Swamy MK, Sinniah UR. Plectranthus amboinicus (Lour.) Spreng: Botanical, Phytochemical, Pharmacological and Nutritional Significance. Molecules.2016;21. https://doi.org/10.3390/molecules21040369.

11. Patra AK, Saxena J. A new perspective on the use of plant secondary metabolites to inhibit methanogenesis in the rumen. Phytochemistry. 2010;71:1198-222. https://doi.org/10.1016/j.phytochem.2010.05.010.

12. Damanik R. Torbangun (Coleus amboinicus Lour): A bataknese traditional cuisine perceived as lactagogue by bataknese lactating women in Simalungun, North Sumatera. Indonesia JHumLact. 2009;25:64-72. https://doi.org/10.1177/0890334408326086.

13. YanzaYR Szumacher-StrabelM, Bryszak M, Gao M, Kolodziejski P, Stochmal A, Slusarczyk S, Patra AK, Cieslak A. Coleus amboinicus (Lour.) leaves as a modulator of ruminal methanogenesis and biohydrogenation in vitro. JAnim Sci. 2018;96:4868-81. https://doi.org/10.1093/jas/sky321.

14. ŚlusarczykS CA, Yanza YR, Szumacher-Strabel M, Varadyova Z, Stafiniak M, Wojnicz D, Matkowski A. Phytochemical Profile and Antioxidant Activities of Coleus amboinicus Lour. Cultivated in Indonesia Poland Molecules. 2021;26(10):2915. https://doi.org/10.3390/molecules26102915.

15. Czerkawski JW, Breckenridge G. Design and development of a long-term rumen simulation technique (Rusitec). BrJNutr.1977;38:371-384. https://doi.org/10.1079/bjn19770102.

16. McDougall E. Studies on Ruminant Saliva. The composition and output of sheep`s saliva. Biochem J. 1947;43:99-109.

17. Grummer RR, Luck ML, Barmore JA. Rumen Fermentation and Lactation Performance of Cows Fed Roasted Soybeans and Tallow. J Dairy Sci. 1993;76:2674-81. https://doi.org/10.3168/jds.S0022-0302(93)77603-1.

18. Grochowska E, Lisiak D, Akram MZ, Adeniyi OO, Luhken G, Borys B. Association of a polymorphism in exon 3 of the IGF1R gene with growth, body size, slaughter and meat quality traits in Colored Polish Merino sheep. Meat Sci. 2021;172:108314. https://doi.org/10.1016/j.meatsci.2020.108314.

19. Grau R, Hamm R. Eine einfacheMathodezurBestimmung der Wasserbindung in Fleisch. Fleischwirtschaft. 1952;4:295-7.

20. Pohja NS, Ninivaara FP. Die Bestimmung der Wasserbindung des Fleischesmittels der Konstandrückmethods. Fleischwirschaft. 1957;9:193-5.

21. Barylko-Pikielna N. Zarysanalizysensorycznejżywności. Warszawa: WydawnictwoNaukowo-Techniczne.1975.

22. AOAC. Official Methods of Analysis of AOAC International. 18th ed. Gaithersburg: MD AOAC International; 2007.

23. Van Soest PJ, Robertson JB, Lewis BA. Methods for Dietary Fiber, Neutral Detergent Fiber, and Nonstarch Polysaccharides in Relation to Animal Nutrition. JDairy Sci. 1991;74:3583-97. https://doi.org/10.3168/jds.S0022-0302(91)78551-2.

24. Varadyova Z, Kisidayova S, Cobanova K, Gresakova L, Babjak M, Konigova A, Dolinska MU, Varady M. The impact of a mixture of medicinal herbs on ruminal fermentation, parasitological status and hematological parameters of the lambs experimentally infected with Haemonchuscontortus. Small Ruminant Research. 2017;151:124-32. https://doi.org/10.1016/j.smallrumres.2017.04.023.

25. Kozłowska M, Cieslak A, Jozwik A, El-Sherbiny M, Gogulski M, Lechniak D, Gao M, Yanza YR, Vazirigohar M, Szumacher-Strabel M. Effects of partially replacing grass silage by lucerne silage cultivars in a high-forage diet on ruminal fermentation, methane production, and fatty acid composition in the rumen and milk of dairy cows. Anim Feed SciTechnol. 2021;277:114959. https://doi.org/10.1016/j.anifeedsci.2021.114959.

26. Michalowski T, Harmeyer J, Breves G. The passage of protozoa from the reticulo-rumen through the omasum of sheep. Br J Nutr. 1986;56:625-34. https://doi.org/10.1079/bjn19860143.

27. Jozefiak D, Kieronczyk B, Juskiewicz J, Zdunczyk Z, Rawski M, Długosz J, Sip A, Hojberg O. Dietary nisin modulates the gastrointestinal microbial ecology and enhances growth performance of the broiler chickens. PLoS One. 2013;8:1-11. https://doi.org/10.1371/journal.pone.0085347.

28. SolivaCR, Meile L, Cieślak A, Kreuzer M, Machmuller A. Rumen simulation technique study on the interactions of dietary lauric and myristic acid supplementation in suppressing ruminal methanogenesis. BrJNutr. 2004;92:689-700. https://doi.org/10.1079/bjn20041250.

29. Yu Y, Lee C, Kim J, Hwang S. Group-specific primer and probe sets to detect methanogenic communities using quantitative real-time polymerase chain reaction. BiotechnolBioeng. 2005;89:670-9. https://doi.org/10.1002/bit.20347.

30. Zeng J, Bian Y, Xing P, Wu QL. Macrophyte species drive the variation of bacterioplankton community composition in a shallow freshwater lake. Appl EnvironMicrobiol. 2012;78:177-84. https://doi.org/10.1128/AEM.05117-11.

Page $26 / 29$ 
31. WangRF, Cao WW, Cerniglia CE. PCR detection of Ruminococcus spp. in human and animal faecal samples. MolCell Probes. 1997;11:25965. https://doi.org/10.1006/mcpr.1997.0111.

32. Poeker SA, Geirnaert A, Berchtold L, Greppi A, Krych L, Steinert RE, De Wouters T, Lacroix C. Understanding the prebiotic potential of different dietary fibers using an in vitro continuous adult fermentation model (PolyFermS). SciRep.2018;8:1-12. https://doi.org/10.1038/s41598-018-22438-y.

33. Denman SE, McSweeney CS. Development of a real-time PCR assay for monitoring anaerobic fungal and cellulolytic bacterial populations within the rumen. FEMS Microbiol Ecol. 2006;58:572-82. https://doi.org/10.1111/j.1574-6941.2006.00190.x.

34. Potu RB, AbuGhazalehAA HastingsD, Jones K, Ibrahim SA. The effect of lipid supplements on ruminal bacteria in continuous culture fermenters varies with the fatty acid composition. JMicrobiol. 2011;49:216-23. https://doi.org/10.1007/s12275-011-0365-1.

35. Li M, Penner GB, Hernandez-Sanabria E, Oba M, Guan LL. Effects of sampling location and time, and host animal on assessment of bacterial diversity and fermentation parameters in the bovine rumen. J ApplMicrobiol. 2009;107:1924-34. https://doi.org/10.1111/j.13652672.2009.04376.x.

36. Minuti A, Palladino A, Khan MJ, Alqarni S, Agrawal A, Piccioli-Capelli F, Hidalgo F, Cardoso FC, Trevisi E, Loor JJ. Abundance of ruminal bacteria, epithelial gene expression, and systemic biomarkers of metabolism and inflammation are altered during the peripartal period in dairy cows. J Dairy Sci. 2015;98L:8940-51. https://doi.org/10.3168/jds.2015-9722.

37. Cieslak A, El-Sherbiny M, Szczechowiak J, Kowalczyk D, Pers-Kamczyc E, Bryszak M, Szulc P, Jozwik A, Szumacher-Strabel M. Rapeseed and fish oil mixtures supplied at low dose can modulate milk fatty acid composition without affecting rumen fermentation and productive parameters in dairy cows. Anim Sci Pap Rep. 2015;33:357-72.

38. Urrutia O, Soret B, Insausti K, Mendizabal JA, Purroy A, Arana A. The effects of linseed or chia seed dietary supplementation on adipose tissue development, fatty acid composition, and lipogenic gene expression in lambs. Small Ruminant Res. 2015;123:204-11. https://doi.org/10.1016/j.smallrumres.2014.12.008.

39. Sitarek P, Toma M, Ntungwe E, Kowalczyk T, Skala E, Wieczfinska J, Sliwinski T, Rijo P. Insight the biological activities of selected abietane diterpenes isolated from plectranthus spp. Biomolecules. 2020;10:1-13. https://doi.org/10.3390/biom10020194.

40. Szumacher-Strabel M, Stochmal A, Cieslak A, Kozlowska M, Kuznicki D, Kowalczyk M, Oleszek W. Structural and quantitative changes of saponins in fresh alfalfa compared to alfalfa silage. J Sci Food Agric. 2018;99:2243-50. https://doi.org/10.1002/jsfa.9419.

41. Patra AK. Recent advances in measurement and dietary mitigation of enteric methane emissions in ruminants. Front Vet Sci. 2016;3:1-17. https://doi.org/10.3389/fvets.2016.00039.

42. Vargas JE, Andres S, Snelling TJ, Lopez-Ferreras L, Yanez-Ruíz DR, García-Estrada C, Lopez S. Effect of sunflower and marine oils on ruminal microbiota, in vitro fermentation and digesta fatty acid profile. Front Microbiol. 2017;8:1-15. https://doi.org/10.3389/fmicb.2017.01124.

43. Cieslak A, Zmora P, Stochmal A, Pecio L, Oleszek W, Pers-Kamczyc E, Szczechowiak J, Nowak A, Szumacher-Strabel M. Rumen antimethanogenic effect of Saponaria officinalis L. phytochemicals in vitro. J Agric Sci. 2014;152:981-93. https://doi.org/10.1017/S0021859614000239.

44. Cobellis G. Yu Z, Forte C, Acuti G, Trabalza-Marinucci M. Dietary supplementation of Rosmarinus officinalis L. leaves in sheep affects the abundance of rumen methanogens and other microbial populations. J Anim Sci Biotechnol. 2016;7:1-8. https://doi.org/10.1186/s40104016-0086-8.

45. Patra AK, Yu Z. Effective reduction of enteric methane production by a combination of nitrate and saponin without adverse effect on feed degradability, fermentation, or bacterial and archaeal communities of the rumen. Bioresour Technol. 2013;148:352-60. https://doi.org/10.1016/j.biortech.2013.08.140.

46. Krause DO, Denman SE, Mackie RI, Morrison M, Rae AL, Attwood GT, McSweeney CS. Opportunities to improve fiber degradation in the rumen: Microbiology, ecology, and genomics. FEMS Microbiol Rev. 2003;27:663-93. https://doi.org/10.1016/S0168-6445(03)00072-X.

47. Devillard E, Bera-Maillet C, Flint HJ, Scott KP, Newbold CJ, Wallace RJ, Jouany JP, Forano E. Characterization of XYN10B, a modular xylanase from the ruminal protozoan Polyplastronmultivesiculatum, with a family 22 carbohydrate-binding module that binds to cellulose. Biochem J. 2003;373:495-503. https://doi.org/10.1042/BJ20021784.

48. De Nardi R, Marchesini G, Li S, Khafipour E, Plaizier KJC, Gianesella M, Ricci R, Andrighetto I, Segato S. Metagenomic analysis of rumen microbial population in dairy heifers fed a high grain diet supplemented with dicarboxylic acids or polyphenols. BMC Vet Res. 2016;12:1-9. https://doi.org/10.1186/s12917-016-0653-4.

49. Moss AR, Jouany JP, Newbold J. Methane production by ruminants: Its contribution to global warming. Anim Res. 2000;49:231-53. https://doi.org/10.1051/animres:2000119.

50. Balcells J, Aris A, Serrano A, Seradj AR, Crespo J, Devant M. Effects of an extract of plant flavonoids (bioflavex) on rumen fermentation and performance in heifers fed high-concentrate diets. J Anim Sci. 2012;90:4975-84. https://doi.org/10.2527/jas.2011-4955.

Page $27 / 29$ 
51. Ungerfeld EM. Metabolic Hydrogen Flows in Rumen Fermentation: Principles and Possibilities of Interventions. Front Microbiol. $2020 ; 11$. https://doi.org/10.3389/fmicb.2020.00589.

52. Khiaosa-ard R, Mahmood M, Lerch F, Traintinger FP, Petri RM, Munnich M, Zebeli Q. Physicochemical stressors and mixed alkaloid supplementation modulate ruminal microbiota and fermentation in vitro. Anaerobe. 2020;65:102263. https://doi.org/10.1016/j.anaerobe.2020.102263.

53. Hartinger T, Gresner N, Sudekum KH. Does intra-ruminal nitrogen recycling waste valuable resources? A review of major players and their manipulation. J Anim Sci Biotechnol. 2018;9:1-21. https://doi.org/10.1186/s40104-018-0249-x.

54. Buccioni A, Pauselli M, Minieri S, Roscini V, Mannelli F, Rapaccini S, Lupi P, Conte G, Serra A, Cappucci A, Brufani L, Ciucci F, Mele M. Chestnut or quebracho tannins in the diet of grazing ewes supplemented with soybean oil: Effects on animal performances, blood parameters and fatty acid composition of plasma and milk lipids. Small Ruminant Res. 2017;153:23-30. https://doi.org/10.1016/j.smallrumres.2017.05.006.

55. Liu S, Huang J, Wang X, Ma Y. Transcription factors regulate adipocyte differentiation in beef cattle. Anim Genet. 2020;51:351-7. https://doi.org/10.1111/age.12931.

56. Garnsworthy PC, Feng S, Lock AL, Royal MD. Short communication: Heritability of milk fatty acid composition and stearoyl-CoA desaturase indices in dairy cows. J Dairy Sci. 2010;93:1743-8. https://doi.org/10.3168/jds.2009-2695.

57. Pewan SB, Otto JR, Huerlimann R, Budd AM, Mwangi FW, Edmunds RC, Holman BWB, Henry MLE, Kinobe RT, Adegboye OA, Malau-Aduli M. Genetics of omega-3 long-chain polyunsaturated fatty acid metabolism and meat-eating quality in Tattykeel Australian white lambs. Genes (Basel). 2020;11. https://doi.org/10.3390/genes11050587.

58. Pewan SB, Otto JR, Huerlimann R, Budd AM, Mwangi FW, Edmunds RC, Holman BWB, Henry MLE, Kinobe RT, Adegboye OA, Malau-Aduli M. Effects of fatty acids on meat quality: A review. Meat Sci. 2004;66:21-32. https://doi.org/10.1016/S0309-1740(03)00022-6.

59. Vasta V, Luciano G. The effects of dietary consumption of plants secondary compounds on small ruminants' products quality. Small Ruminant Res. 2011;101:150-9. https://doi.org/10.1016/j.smallrumres.2011.09.035.

60. Wood JD, Richardson RI, Nute GR, Fisher AV, Campo MM, Kasapidou E, Sheard PR, Enser M. Effects of fatty acids on meat quality: a review. Meat Sci. 2003;66(1):21-32. https://doi.org/10.1016/S0309-1740(03)00022-6.

61. Forman H, Davies K, Ursini F. How do nutritional antioxidants really work: nucleophilic tone and para-hormesis versus free radical scavenging in vivo. Free RadicBiol Med. 2014;66:24-35. https://doi.org/10.1016/j.freeradbiomed.2013.05.045.

62. Font-i-Furnols M, Guerrero L. Consumer preference, behavior and perception about meat and meat products: An overview. Meat Sci. 2014;98:361-71. https://doi.org/10.1016/j.meatsci.2014.06.025.

63. Francisco A, Alves SP, Portugal PV, Dentinho MT, Jerónimo E, Sengo S, Almeida J, Bressan MC, Pires VMR, Alfaia CM, Prates JAM, Bessa RJB, Santos-Silva J. Effects of dietary inclusion of citrus pulp and rockrose soft stems and leaves on lamb meat quality and fatty acid composition. Animal. 2018;12:872-81. https://doi.org/10.1017/S1751731117002269.

64. Dentinho MTP, Paulos K, Francisco A, Belo AT, Jerónimo E, Almeida J, Bessa RJB, Santos-Silva J. Effect of soybean meal treatment with Cistus ladanifer condensed tannins in growth performance, carcass and meat quality of lambs. Livest Sci. 2020;236:104021. https://doi.org/10.1016/j.livsci.2020.104021.

65. Moran L, Andres S, Bodas R, Prieto N, Giraldez FJ. Meat texture and antioxidant status are improved when carnosic acid is included in the diet of fattening lambs. Meat Sci. 2012;91:430-4.

66. Yusuf AL, Adeyemi KD, Roselina K, Alimon AR, Goh YM, Samsudin AA, Sazili AQ. Dietary supplementation of different parts of Andrographis paniculata affects the fatty acids, lipid oxidation, microbiota, and quality attributes of longissimus muscle in goats. Food Res Int. 2018;111:699-707.

67. Biondi L, Randazzo CL, Russo N, Pino A, Natalello A, Van Hoorde K, Caggia C. Dietary Supplementation of Tannin-Extracts to Lambs: Effects on Meat Fatty Acids Composition and Stability and on Microbial Characteristics. Foods (Basel). 2019;8(10):469. https://doi.org/10.3390/foods8100469.

68. Zembayashi M, Lunt DK, Smith SB. Dietary tea reduces the iron content of beef. Meat Sci. 1999;53:221-6.

69. Priolo A, Vasta V. Effects of tannin-containing diets on small ruminant meat quality. Ital J Anim Sci. 2007;6(1):527-30.

70. Priolo A, Waghorn G, Lanza M, Biondi L, Pennisi P. Polyethylene glycol as a means for reducing the impact of condensed tannins in carob pulp: effects on lamb growth, performance and meat quality. J Anim Sci. 2000;78:810-6.

71. Garg SK, Makkar HPS, Nagal KB, Sharma SK, Wadhwa DR, Singh B. Oak (Quercus incana) leaf poisoning in cattle. Vet Hum Toxicol. 1992;34:161-4.

72. Andres S, Tejido ML, Bodas R, Moran L, Prieto N, Blanco C, Giraldez FJ. Quercetin dietary supplementation of fattening lambs at $0.2 \%$ rate reduces discolouration and microbial growth in meat during refrigerated storage. Meat Sci. 2013;93:207-12.

https://doi.org/10.1016/j.meatsci.2012.08.023.

Page 28/29 
Figures

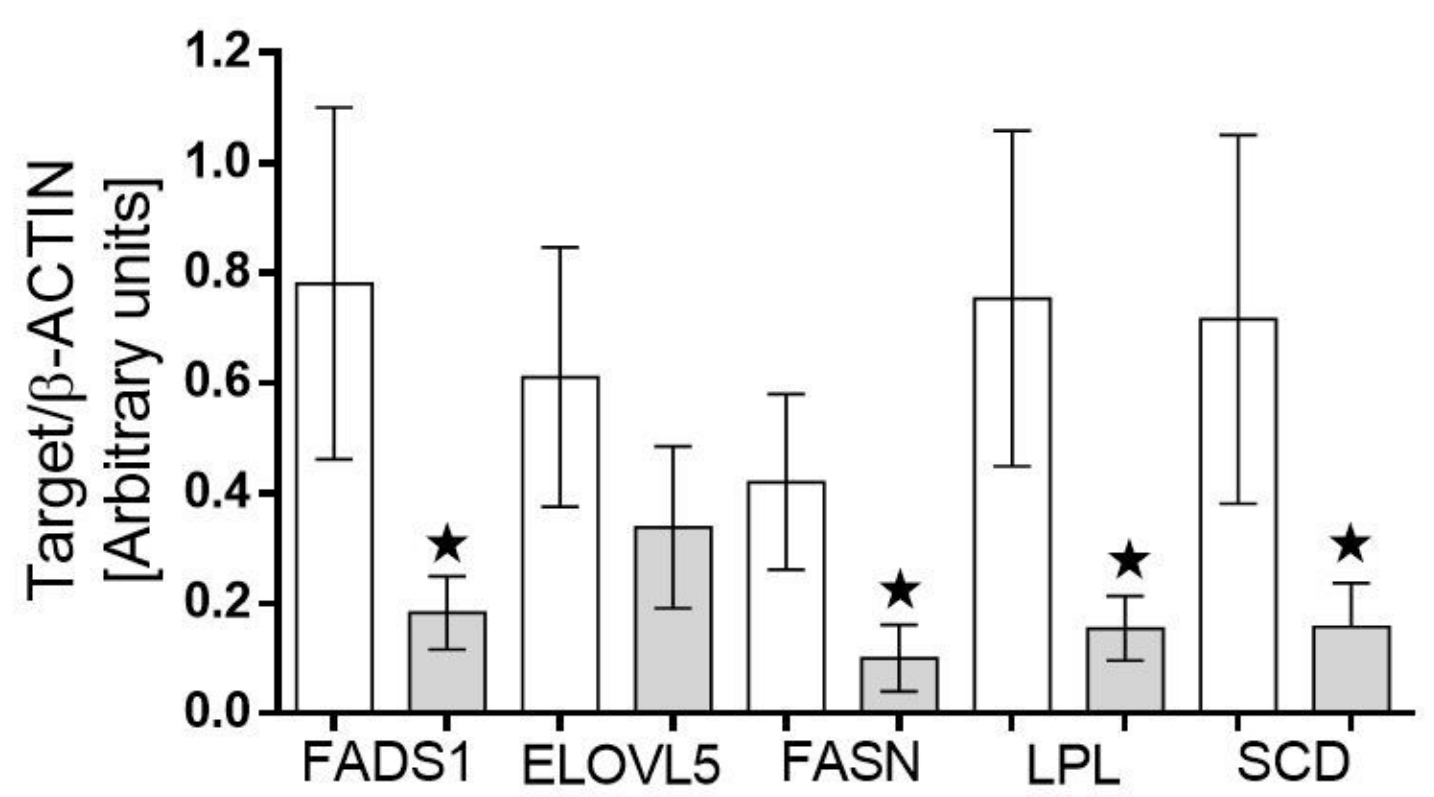

Figure 1

Comparison on LT gene expressions of lambs receiving CON and CAL diet Legends: (CON; white colour); CAL diet (CAL; grey colour); Gene expressions are fatty acid desaturase 1 (FADS1), fatty acid elongase 5 (ELOVL5), fatty acid synthase (FASN), lipoprotein lipase (LPL), andstearoyl-CoAdesaturase (SCD)in the longissimus thoracis muscle of growing lambs; The symbol * indicates significant difference between treatments.

\section{Supplementary Files}

This is a list of supplementary files associated with this preprint. Click to download.

- Onlinefloatimage2.png 